\title{
Innovation-Centric Cluster Business Model: Findings from a Design-Oriented Literature Review
}

\author{
Evgeniya Lupova-Henry ${ }^{1}$ \\ University of Neuchâtel, Switzerland \\ evgeniya.lupova@unine.ch \\ Sam Blili \\ University of Neuchâtel, Switzerland \\ Cinzia Dal Zotto \\ University of Neuchâtel, Switzerland
}

\begin{abstract}
How should a cluster be designed to foster the innovativeness of its members? In this article, we view self-aware and organised clusters as "meta-organisations" which can deliberately shape their internal structures through design-based interventions. To formulate interventions for cluster design fostering its innovativeness, we adopt a methodology combining a systematic literature review and a design-oriented synthesis. We distinguish between six cluster business model elements: actors and their roles, resources and capabilities, value flows, governance, value propositions and value-creating activities. To gain insight into the properties of these elements conducive to cluster innovativeness, we review literature at the intersection of cluster, metaorganisation, business model and innovation studies. Our study allows to consolidate the extant research into "organised" clustering and the drivers of the cluster actors' innovativeness. It also helps identify several important unanswered questions in the literature and to suggest potentially fruitful directions for further work.
\end{abstract}

1 Correspondence: evgeniya.lupova@unine.ch University of Neuchâtel, A.-L. Breguet 2, 2000 Neuchâtel, Switzerland. 


\section{Keywords}

cluster - innovation - business model - meta-organisation - systematic literature review - design science

\section{Arabic}

\section{نموذج الأعمال التجارية لمجمعات الابتكار: نتائج مراجعة الأدبيات القائمة على التصميم}

Evgeniya Lupova-Henry, Sam Blili, Cinzia Dal Zotto

الملخص

كيف ينبني تصميم المجمعات لتعزيز الروح الابتكارية لأعضائها؟ نعتبر في هذا المقال أن أن أمنات

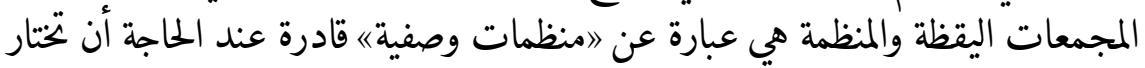

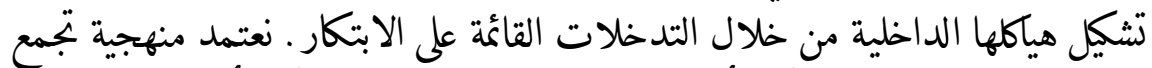

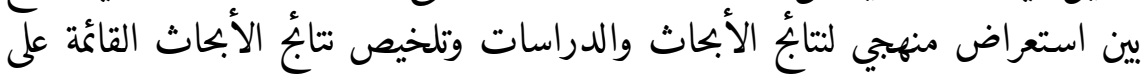

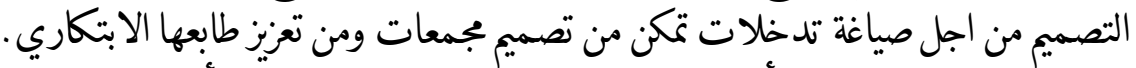

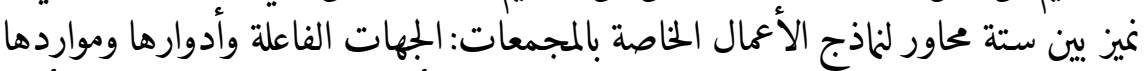

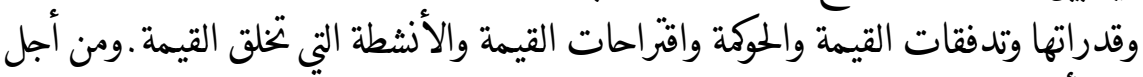

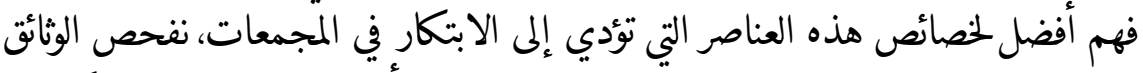

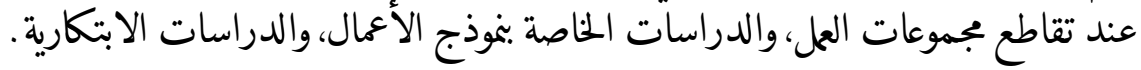

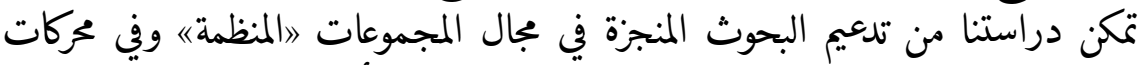

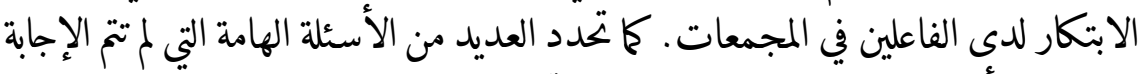
عليها في الأدبيات وتقترح مزيد التعمق في التجاهات مثمرة محتلة. 

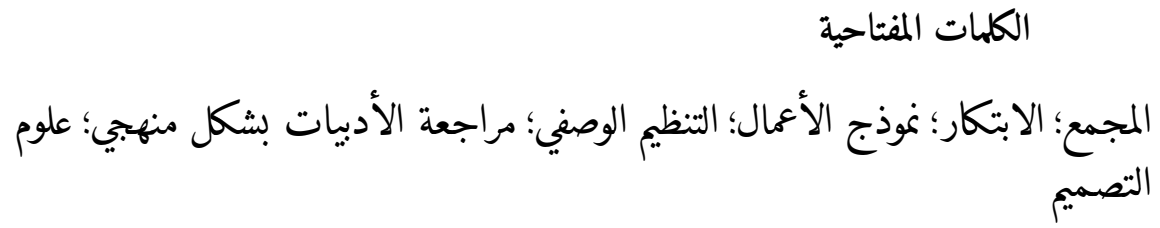

\title{
Chinese
}

\section{以创新为中心的集群商业模式:来自设计导向的文 献综述的发现}

\author{
Evgeniya Lupova-Henry, Sam Blili, Cinzia Dal Zotto
}

\section{摘要}

如何设计集群以促进其成员的创新? 在本文中, 我们将自我意识和组织化的集群视 为 “元组织”, 它们可以通过基于设计的干预来刻意塑造其内部结构。为了制定对 促进创新的集群设计的干预措施, 我们采用将系统的文献综述和面向设计的综合相 结合的方法。我们区分了六个集群商业模式要素: 主体及其角色、资源和能力、价 值流、治理、价值主张和价值创造活动。为了深入了解有助于集群创新的这些要素 的属性, 我们回顾了集群、元组织、商业模式和创新研究相矢文献。我们的研究可 以巩固目前对 “有组织的” 集群和驱动集群主体创新的研究。它还有助于确定文献 中几个重要的尚未回答的问题, 为进一步研究提供有效指南。

\section{关键词}

集群, 创新, 商业模式, 元组织, 系统的文献综述, 设计科学 


\title{
French
}

\section{Modèle d'entreprise de cluster centré sur l'innovation : résultats d'une revue de la littérature axée sur la conception}

\author{
Evgeniya Lupova-Henry, Sam Blili, Cinzia Dal Zotto
}

\section{Résumé}

Comment un cluster doit-il être conçu pour favoriser l'innovation de ses membres? Dans cet article, nous considérons les clusters auto-conscients et organisés comme des «méta-organisations » qui peuvent délibérément façonner leurs structures internes grâce à des interventions axées sur la conception. Pour formuler des interventions pour la conception de clusters favorisant leur caractère innovant, nous adoptons une méthodologie combinant une revue systématique de la littérature et une synthèse orientée vers la conception. Nous distinguons six éléments du modèle d'entreprise de cluster : les acteurs et leurs rôles, les ressources et les capacités, les flux de valeur, la gouvernance, les propositions de valeur et les activités créatrices de valeur. Pour mieux comprendre les propriétés de ces éléments vecteurs de l'innovation des clusters, nous faisons une revue de la littérature à la croisée des domaines de recherche des clusters, de la méta-organisation, des modèles d'affaires et de l'innovation. Notre étude permet de consolider les recherches existantes sur le clustering « organisé » et les moteurs de l'innovation des acteurs du cluster. Elle permet également d'identifier plusieurs questions importantes restées sans réponse dans la littérature et de suggérer des pistes potentiellement fructueuses pour des travaux ultérieurs.

\section{Mots clés}

cluster - innovation - modèle d'affaires - méta-organisation - revue systématique de la littérature - science de la conception 


\title{
Portuguese
}

\section{Modelo de negócios de cluster centrado na inovação: resultados de uma revisão da literatura orientada para o design}

\author{
Evgeniya Lupova-Henry, Sam Blili, Cinzia Dal Zotto
}

\section{Resumo}

Como um cluster deve ser projetado para promover a capacidade de inovação de seus membros? Neste artigo, nós observamos clusters autoconscientes e organizados como "meta-organizações" que podem moldar deliberadamente suas estruturas internas por meio de intervenções baseadas em design. Para formular intervenções para o design de clusters que promovam sua capacidade de inovação, adotamos uma metodologia que combina uma revisão sistemática da literatura e uma síntese orientada. Nós distinguimos entre seis elementos do modelo de negócios do cluster: os atores e suas funções, os recursos e capacidades, os fluxos de valor, a governança, as proposições de valor e as atividades de criação de valor. Para obter uma visão sobre as propriedades desses elementos que conduzam à inovação do cluster, nós revisamos a literatura na interseção de cluster, meta-organização, modelo de negócios e estudos de inovação. Nosso estudo permite consolidar a pesquisa existente em um agrupamento "organizado" e os impulsionadores da inovação dos atores do cluster. Isso também ajuda a identificar várias questões importantes sem resposta na literatura e a sugerir direções potencialmente frutíferas direções para trabalhos futuros.

\section{Palavras-chave}

cluster - inovação - modelo de negócios - meta-organização - revisão sistemática da literatura - ciência do design 


\title{
Russian
}

\section{Бизнес-модель инновационного кластера: результаты дизайн-ориентрованного обзора литературы}

\author{
Евгения Лупова-Анри, Сэм Блили, Цинзиа Даль Зотто
}

\begin{abstract}
Аннотация
Каким должен быть кластер, чтобы способствовать инновационности своих участников? В настоящей статье мы рассматриваем самостоятельные и организованные кластеры как мета-организации, которые могут планомерно внедрять дизайн-решения и, таким образом, формировать свои внутренние структуры. Для того, чтобы предложить возможные дизайн-решения для формирования структуры кластера, ориентированного на инновации, мы адаптировали методологию, сочетающую в себе систематический обзор литературы и дизайн-ориентированный подход. Мы выделили шесть элементов бизнес-моделей кластеров:участники и их роли, ресурсы и возможности, потоки ценности, управление, ценностное предложение и деятельность по созданию ценности. Для того, чтобы получить представление о характеристиках этих элементов по отношению к инновационности кластера, мы провели обзор литературы, посвященной тематике кластеров, мета-организаций, бизнес-моделей и исследованиям инноваций. Наше исследование позволяет консолидировать результаты существующих исследований и выделить драйверы инновационности участников кластера. Это исследование также помогает идентифицировать важные вопросы, на которые литература не дает ответа на настоящий момент, и предложить потенциально перспективные направления для дальнейших исследований.
\end{abstract}

\section{Ключевые слова}

кластер - инновации - бизнес-модель - мета-организация - систематический обзор литературы - теория дизайна 


\title{
Spanish
}

\section{Modelo de negocio de clúster centrado en la innovación: resultados de una revisión de la literatura orientada al diseño}

\author{
Evgeniya Lupova-Henry, Sam Blili, Cinzia Dal Zotto
}

\section{Resumen}

¿Cómo debe diseñarse un cluster para fomentar la innovación de sus miembros? En este artículo, consideramos que los clústeres autoconscientes y organizados son "metaorganizaciones" que pueden dar forma deliberadamente a sus estructuras internas a través de intervenciones basadas en el diseño. Para formular intervenciones para el diseño de clústeres fomentando su innovación, adoptamos una metodología que combina una revisión sistemática de la literatura y una síntesis orientada al diseño. Distinguimos entre seis elementos del modelo de negocio de clúster: actores y sus roles, recursos y capacidades, flujos de valor, gobernanza, propuestas de valor y actividades de creación de valor. Para obtener información sobre las propiedades de estos elementos que propician la innovación del clúster, revisamos la literatura en la intersección de los estudios de cluster, meta-organización, modelo de negocio e innovación. Nuestro estudio permite consolidar la investigación existente en clustering "organizado" y la innovación de los actores del clúster. También ayuda a identificar varias preguntas importantes sin respuesta en la literatura y a sugerir instrucciones potencialmente fructíferas para seguir trabajando.

\section{Palabras clave}

cluster - innovación - modelo de negocio - meta-organización - revisión sistemática de la literatura - ciencia del diseño

\section{Introduction}

"Managed" clusters have become one of the major policy tools in both developed and developing countries in their quest for innovation and 
knowledge-based regional economic development (Sölvell et al. 2003, Ketels et al. 2006, Lindqvist et al. 2013). However, while hopes are high for the potential of such clusters, research has been inconclusive as to whether they can live up to their promise (Castells and Hall 1994, Hospers et al. 2009). We suggest that this is partly due to the lack of appreciation of the differences between the "organic" or "spontaneous" and "managed" clustering.

Continuing a recent line of studies (Gadille et al. 2013, Viachka 2013, Leys and Joffre 2014, Gimet and Grenier 2018), in this paper, we adopt a metaorganisational perspective on self-aware and organised clusters. We view these as "organisations of organisations" whereby their constituents retain their autonomy and are not bound by formal authority but are driven by a systemlevel goal (Ahrne and Brunsson 2008, Gulati et al. 2012, Berkowitz and Dumez 2016). This point of view highlights the role of collective value creation and suggests that no single "architect" - such as a cluster management organisation can be in charge of the steering in a meta-organisational setting (Gulati et al. 2012). Furthermore, the "meta-organisational" view calls for the application of the frameworks developed in the fields of organisation and management studies, such as business models (Arend 2013), which can provide insight into collective value creation in clusters.

The aim of this research is twofold. First, we aim to take stock of the extant research into the drivers of collective innovativeness in clusters functioning as "meta-organisations". To do so, we adopt the perspective of organisation studies and strategic management scholarship. Specifically, we leverage the potential of the "business model" concept for the understanding of value creation in complex, "non-traditional", organisational settings (Arend 2013). Recognising that clusters may be driven by different logics which shape their strategic choices (cf. Sölvell et al. 2003), we focus on innovation-centric clusters, i.e. those which prioritise innovation as one of their key strategic directions. We thus seek to understand how the elements of the cluster business model should be designed to foster the innovativeness of its members.

The second goal of this paper is to enable evidence-based management (cf. Rousseau 2012) in clusters. To do so, we combine the systematic literature review with the design-oriented synthesis approach (Tranfield et al. 2003, Denyer et al. 2008, Briner and Denyer 2012) drawing upon the literature at the intersection of meta-organisation, cluster, innovation and business model studies. This allows distilling the findings of the literature review in the form of actionable propositions for the innovation-centric cluster business model design. Specifically, we follow the "CIMO-logic" proposed by Denyer et al. (2008) which includes four elements: Context, Interventions, Generative Mechanisms and Outcomes. We apply the framework throughout this study to 
formulate the research question, to analyse and synthesise the literature and then to present our findings. We thus address the following research question: - How should the cluster business model be designed so as to trigger the generative mechanisms fostering cluster innovativeness in specific contexts?

In this research, we focused on six elements shaping the value creation in clusters: actors and their roles, resources and capabilities, value flows, governance, value propositions and value-creating activities. By analysing their relationship to innovation, we uncovered several crucial attributes of these elements, such as the types of actor roles relevant for cluster innovativeness, the multidimensionality of cluster value propositions, the presence of both formal and informal governance mechanisms, the importance of both tangible and intangible resources and value flows and the existence of five types of value-creating activities in innovation-centric clusters.

The remainder of this article is structured as follows. Section 2 provides a theoretical background applying the meta-organisational perspective to clusters and discussing the implications of such a perspective for cluster business model design. Section 3 describes the research design. In section 4 , we present our findings along the four dimensions of the "CIMO" framework. Section 5 discusses the theoretical and practical implications of the study as well as its limitations and provides suggestions for future research.

\section{Theoretical Background}

The understanding of "innovation" and that of "clusters" and their role as the drivers of the knowledge economy has been evolving over the past decades. In what follows we will present a brief overview of that evolution to make a case for the meta-organisational approach in cluster studies.

\subsection{Clusters, Innovation and Meta-Organisations}

Innovation in spatial agglomerations of firms was noted by Alfred Marshall already in 1890 when he observed that these facilitate knowledge transfer and promote innovation through co-location (Marshall 189o). This line of thinking was further advanced by the Italian school of the "new industrial districts" (e.g. Becattini 1987, 1989) and the GREMI school of the "milieux innovateurs" (Aydalot 1986, Camagni 1995, Castells 1996) in the 1970s-9os. These schools of thought shed light on several important elements of inter-firm network innovativeness, notably, the combination of competition and co-operation between the actors; their conscious engagement in networking activities, and synergies between them. Further to this "re-discovery" of Marshall's industrial 
districts and the new understanding of the drivers of their innovativeness, the first organised support initiatives were launched in the Italian "new industrial districts" in the 1970s-8os. These aimed at supporting the development of already existing industrial districts through the provision of collective research and business services to their members (European Innovation Monitoring System (EIMS) 1993, OECD 2O11).

Another important development in the understanding of innovation in the inter-organisational settings came from the fields of economic geography and organisation and business studies. Notably, two key concepts have been gaining increasing attention: the "innovation systems" (e.g. Lundvall 1992, Nelson 1993, and Breschi and Malerba 1997 on sectoral systems of innovation, Cooke et al. 1997 on regional systems of innovation, and Edquist 1997 on national systems of innovation) and the "ecosystems" (Adner 2006, Adner and Kapoor 2010, Shaw and Allen 2016). These perspectives shed light on the importance of the socio-institutional settings, interfirm communication, interactive learning and knowledge flows between a variety of actors in driving technological change and innovation.

This changing understanding of innovation as a collaborative phenomenon rather than an undertaking of a "lone entrepreneurial hero" was further reflected by the advent of the concepts of the "Triple Helix of UniversityIndustry-Government relations" (Etzkowitz 1993, Etzkowitz and Leydesdorff 1995) and of "open innovation" (Chesbrough et al. 2006). Both models highlight the need to bring industrial innovation closer to public R\&D but are different in their focus (Leydesdorff and Ivanova 2016). The latter is firm-centric and highlights the importance of the firms' relations with external actors for innovation. The former, on the other hand, provides a new understanding of the interactions and the roles of academia, government, and industry in the innovation process. The Triple Helix model implies that academia assumes a novel role in addition to education and research and acts a source of firm-formation and regional development. Governments, in turn, support the new enterprises by creating a favourable regulatory environment, providing tax incentives and public venture capital and engaging in public-private partnerships. Finally, industry plays an important role in training and research together with the universities. This model is commonly instantiated by networks of innovation, clusters and university centres (Etzkowitz 2002, 2012, Etzkowitz and Klofsten 2005).

These developments show a shift of our understanding of both innovation and clusters: the former is now seen as a collaborative phenomenon, while the latter are increasingly perceived as results of conscious efforts of the key innovation actors, rather than spontaneous agglomerations of organisations. 
Indeed, clusters are increasingly perceived as "managed" entities or "metaorganisations" representing a new form of a "decided social order" (cf. Gadille et al. 2013, Viachka 2013, Leys and Joffre 2014, Lupova-Henry et al. 2019). This "meta-organisational turn" in cluster studies has several important implications.

First, viewing clusters as meta-organisations implies a two-way relationship between clusters and their environments: these are not only shaped by their contexts but can deliberately act upon and transform these, just like individual organisations (King et al. 2010). This contrasts with the more "traditional" perspective seeing clusters as spontaneous spatial phenomena which can or should be acted upon by the policy-makers (e.g. Porter 1998a, Motoyama 2008). This calls for a more rigorous analysis of the cluster-environment interactions, taking into account different contextual levels (e.g. regional vs. national) and their influence on deliberate cluster design in its quest for innovation (Bunnell and Coe 2001).

Second, viewing clusters as meta-organisations means that they can be deliberately "shaped through design-based interventions by their founders and other change agents ..." (van Aken and Romme 20o9: 6), again, just as individual organisations. While most current research focuses on the role of the "cluster management organisation" in cluster development (e.g. Ingstrup 2010, Lefebvre 2013, Coletti and Di Maria 2015), in a meta-organisation, a broader range of actors is involved in strategy- and decision-making (cf. Gulati et al. 2012). Furthermore, in such a context, the role of managers becomes increasingly complex as they face the challenge of managing assets which are not directly owned by their firms (Iansiti and Levien 2004). This requires new analytical and managerial tools, as the traditional ones, such as the value chain or the "Diamond Model" (Porter 1998a), are less well suited to the network forms of organisation (Normann and Ramirez 1993, Stabell and Fjeldstad 1998, Gulati et al. 2012).

Several concepts have been proposed to reflect the networked nature of innovation, such as "virtual" or "meta-value chains" (Raymond and Blili 1997) and "value networks" (Stabell and Fjeldstad 1998, Allee 2000, Lusch et al. 2010). These emphasise the importance of complex dynamic exchanges between the actors in the process of value creation. Moreover, such new organisational tools as business models - notably "open" and "network-embedded" business models - were proposed to better reflect the firms' value creation and capture mechanisms through their exchanges with external stakeholders (Chesbrough 2007, Palo and Tähtinen 2011, Zott et al. 2011, Markides 2013, Bankvall et al. 2017). 


\subsection{Towards an Innovation-Centric Cluster Business Model}

Research has highlighted the potential of business models for identifying, delineating, and analysing the structuring of meta-organisations (Arend 2013). Indeed, business models can be seen as "recipes" which describe the elements of the organisation's activities and the way these interact to produce certain outcomes (Baden-Fuller and Morgan 2010). For individual firms, these elements often include customers, network, resources, financial aspects (revenues and costs) as well as combinations of value-creating activities and governance mechanisms which allow creating and appropriating value (Wirtz et al. 2016, Fjeldstad and Snow 2018). In the meta-organisational context, however, these elements and relations between them will significantly differ (see Figure 1 for an overview).

First, the concept of "customers" is more complex in the meta-organisational setting. Indeed, meta-organisations involve a broad range of stakeholders who may not necessarily be formal members (Berkowitz 2018). On the other hand, the formal members can simultaneously be the owners, co-producers and end-users of the collectively created value (Berkowitz and Bor 2018). The metaorganisational view places the network of actors at the core of its business model since attracting and retaining the "right" categories of members - the strongest ones - is crucial for its survival (Berkowitz and Dumez 2016). Thus, in contrast to the single-firm approaches, where the network is external and complementary to the focal firm, in the meta-organisational setting, the network of actors collectively creating value is a core element with no single actor being central.

Second, when speaking of "resources", in contrast to individual firms, metaorganisations do not own or control resources which are made available by the participants (Gulati et al. 2012). Both tangible and intangible resources are present in a meta-organisational context: rather than being driven by solely financial considerations, the members exchange knowledge and can tap into the pool of resources outside the boundaries of their organisations (Gadille et al. 2013).

Third, while the firm-level view focuses on the intra-firm flows of resources and finance, the meta-organisational approach crosses the firm boundaries to bring to the fore the inter-firm exchanges (Leys and Joffre 2014). Indeed, meta-organisations need to reconcile different identities, facilitate value flows and build trust between the stakeholders pursuing different interests (Brès et al. 2018).

Fourth, within the firm-centric perspective "governance" mostly concerns the value appropriation mechanisms by an individual business or their 
relations with external network actors (e.g. Amit and Zott 2001, Nenonen and Storbacka 2010). In the meta-organisational context, on the other hand, both the distribution of the results of activity between these and value appropriation are of key importance (Azzam and Berkowitz 2018). Furthermore, in meta-organisations, governance combines formal and informal mechanisms and focuses on building the organisational identity, reaching an equilibrium between competitive and cooperative behaviour of its actors, and ensuring that individual values are aligned with those of the meta-organisation as a whole (Gadille et al. 2013, Brès et al. 2018, Gimet and Grenier 2018).

Furthermore, the "value proposition" element in a meta-organisation is multidimensional. Internal value is created by the meta-organisation for its members by allowing to reduce uncertainty and shape a negotiated environment (Azzam and Berkowitz 2018). Internal value proposition depends on the ability of the meta-organisation to provide benefits which otherwise would not be accessible to members (Berkowitz and Dumez 2016, Azzam and Berkowitz 2018). On the other hand, institutional and organisational settings within which meta-organisations function impose external demands and expectations (Jarzabkowski and Fenton 2006, Brès et al. 2018). Indeed, often used as economic development tools, organised clusters are expected to bring value to a broad range of stakeholders in their regions and nations by improving or revitalising regional or national economies (Porter 1998b, Berkowitz 2018).

Finally, concerning the "value-creating activities", in contrast to the intrafirm perspective which describes the activities of a single focal firm, in the meta-organisational context collective activities are at the fore (Ahrne and Brunsson 2005, Gadille et al. 2013, Gimet and Grenier 2018). In metaorganisations, four types of innovation-related activities can be identified: the orchestration of knowledge capabilities, ongoing strategizing, developing public policy and theorising innovation, i.e. developing common frames of reference or value systems (Dougherty and Dunne 2011, Gimet and Grenier 2018). Thus, meta-organisational value-creating activities are of a higher order than the activities of its constituent members.

Figure 1 summarises the discussion above by identifying the main elements of a cluster business model and the relationships between them. Thus, we propose to distinguish between six business model elements shaping the value created by a cluster: actors and their roles, resources and capabilities, value flows, governance, value proposition and value-creating activities. Cluster governance mechanisms are crucial in defining what types of actors will participate in a cluster and how these will exchange their resources and capabilities while engaging in value-creating activities (link I). On the other hand, the external and internal value propositions shape both the governance (link III) and the ways actors engage in value-creating activities (link II). Indeed, cluster 


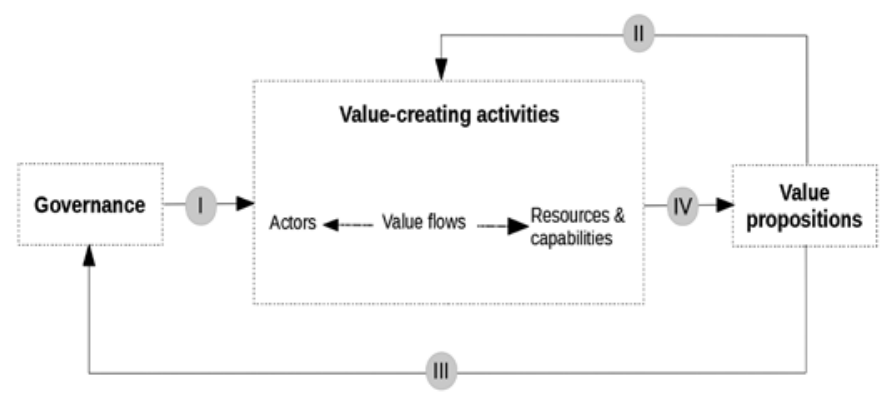

FIGURE 1 Conceptualising the relations between the cluster business model elements

value propositions attract those actors who identify themselves with the cluster's goals, influence the way these collaborate and the value these obtain from participating in the cluster. Finally, by exchanging resources and capabilities and performing a set of value-creating activities actors shape the unique external and internal value propositions (link IV).

\section{$3 \quad$ Research Design}

The goal of our paper is to provide actionable recommendations for innovationcentric cluster business model design and thus enable evidence-based management in clusters. In choosing the most appropriate research design, we were guided by three key considerations. First, due to the orientation of our research towards developing practical recommendations, the methodology had to allow for the formulation of actionable design propositions and to account for the difference in the cluster contexts and their goals. Moreover, to obtain reliable results we aimed at avoiding the potential bias of narrative literature reviews and strived for the transparency and replicability of our study. Finally, given the fragmented nature of the field of research and the large number of studies adopting quantitative methodology, we needed a method flexible enough to integrate both quantitative and qualitative studies. To ensure that these criteria are met, we adopted the systematic literature review method combining it with the design-oriented synthesis approach (Tranfield et al. 2003, Denyer and Tranfield 2006, Denyer et al. 2008).

The design-oriented synthesis proposed by (Denyer et al. 2008) follows the "CIMo-logic" where in certain Contexts (C), a number of Interventions (I) may be taken to trigger Generative Mechanisms (M) leading to certain Outcomes $(\mathrm{O})$. This framework fits our needs in that it allows to formulate actionable guidelines or propositions for cluster design leading to the desired 
outcomes, i.e. cluster innovativeness. It also accounts for the various contextual characteristics which may influence the appropriateness and effectiveness of different approaches to stimulate cluster innovativeness.

The design-oriented synthesis approach, however, does not outline a transparent and replicable process of literature search and selection, being guided by "the pragmatic principle of what works" (Jones and Gatrell 2014: 259). Thus, we chose to combine the design-oriented synthesis with the systematic literature review approach as a way to corroborate the findings of different studies seeking to answer similar questions and, at the same time, avoid any possible bias in selecting the literature sources (Rousseau 2012, Jones and Gatrell 2014).

We thus followed the three stages of a systematic literature review methodology involving (1) planning the review; (2) conducting the review and (3) reporting and dissemination (Tranfield et al. 2003). At the same time, we integrated the "CIMO-logic" in each of these stages, adopting a customised process based on the combination of methodologies proposed by Tranfield et al. (2003), Denyer et al. (2008), and Briner and Denyer (2012). Table 1 describes our research design.

Stage one of the literature review included initial exploratory literature reviews and scoping studies to delimit the boundaries of the research question. An analysis of the available sources of literature was carried out and a decision was made to only include academic peer-reviewed articles and book chapters to ensure higher reliability of the retained literature sources.

Stage two drew upon the information about the field of study obtained during the preliminary exploratory literature review. At this stage, we identified the keywords and search strings. In doing so, we adopted a narrow focus on clusters rather than a broader perspective which would include technoparks, science parks and other instantiations of the Triple Helix model of interactions. This choice was made to ensure the feasibility of our study and the possibility to formulate cluster-specific design interventions. We also formulated the exclusion criteria for the consecutive literature search stage (see Table 2). In doing so, we were guided by two key considerations. First, we sought to only focus on "organised" or "managed" clusters which can be considered as metaorganisations. We thus excluded the studies focusing on the whole industries or other broad concepts such as national innovation systems and cluster policies. Second, we targeted only the studies focusing on the drivers or key success factors of cluster innovativeness and thus allowing to answer our research question. We thus excluded papers which did not describe the relationships between certain aspects of cluster activity and its innovative outcome. 
TABLE 1 Research design - combining the systematic literature review with the 'CIMO-logic'

Stage 1 1.1. Scoping the literature to assess its relevance and size

1.2. Determining the types of studies and data that will answer the research question

1.3. Definition, clarification, and refinement of the research question with the use of the 'CIMo-logic'

Stage 2 2.1. Identification of keywords, search terms and formulating the search strings

2.2. Formulating the inclusion/exclusion criteria

2.3. Querying the literature database

2.4. Selecting the studies according to the pre-defined exclusion/ inclusion criteria

2.5. Extracting data from the literature following the elements of the 'CIMO-logic'

2.6. Conducting a descriptive analysis following the elements of the 'CIMO-logic'

2.7. Conducting a thematic analysis following the elements of the 'CIMO-logic'

Stage 3 3.1 Writing up the article: following the 'CIMo' logic to present the findings of the review

SOURCE: ADAPTED FROM TRANFIELD ET AL. (2003), BRINER AND DENYER (2012)

We carried out the search and selection of the literature in three phases: (A) initial search, (B) refinement and (C) final selection. Each of the phases resulted in a narrowed down list of the retained literature - respectively lists A, $B$, and C. See Table 3 for an overview of the selection process.

The initial search (phase A) was conducted by querying Scopus database and involved six iterations with different search strings based on the pre-defined keywords (Table 2). The choice of the database was guided by the practical considerations of the availability of institutional access to it and the transparency of the search process. To ensure the inclusion of the studies at the intersection of innovation, cluster and business model fields, we only retained the articles that contained at least one keyword from each of the three keyword domains in their titles, abstracts or keyword lists. The period covered all articles available in the database. Only publications in English, French and Russian languages were considered based on the authors' proficiency in these. The initial 
TABLE 2 Keywords and exclusion criteria

\begin{tabular}{|c|c|c|c|}
\hline $\begin{array}{l}\text { Area 1: clusters and } \\
\text { meta-organisations }\end{array}$ & $\begin{array}{l}\text { Area 2: } \\
\text { innovation }\end{array}$ & $\begin{array}{l}\text { Area 3: business } \\
\text { model }\end{array}$ & Exclusion criteria \\
\hline manag* cluster, & innovat* & govern*, financ*, & (1) Lack of focus on \\
\hline cluster manag*, & & value flow, value & the drivers of cluster \\
\hline cluster initiative, & & ${ }^{*}$ creat $^{*}$, value & innovativeness, \\
\hline cluster organis*, & & capture, value offer*, & (2) micro-level \\
\hline organis* cluster, & & value propos*, & approach with \\
\hline self-aware cluster, & & business model & the predominant \\
\hline cluster orchestr*, & & & focus on individual \\
\hline cluster design, pole de & & & cluster members, \\
\hline competitivite, industr* & & & (3) macro-level \\
\hline cluster, innovat* & & & focus on policies, \\
\hline cluster, m?ta-organis* & & & industries, \\
\hline design, m?ta organis* & & & innovation systems, \\
\hline manage*, cluster & & & (4) cluster analysis \\
\hline facilit*, m?ta-organi* & & & as a technique \\
\hline
\end{tabular}

exercise was conducted in March 2017 and a subsequent search was carried out in September 2019. After the removal of the duplicates and retracted articles from the query results, we obtained List A comprising 387 entries.

Phase $\mathrm{B}$ involved the refinement of the literature list by analysing the titles and abstracts of the articles to retain only those fitting the scope of the research based on the exclusion criteria. This phase led to the narrowing down of the number of articles to 160 (List B). The most common reason for article exclusion was the lack of focus on the drivers of cluster innovativeness $(61 \%$ of excluded articles), the second most common reason was a macro-level focus on national innovation systems, innovation and cluster policies or whole industries $(35 \%)$.

The final selection (phase C) involved analysing the full texts of the 160 articles in List B and retaining those fitting the scope of the study based on the same exclusion criteria. At this stage, the most common reason for article exclusion was, again, the absence of the focus on the drivers of cluster innovativeness. This phase resulted in List $\mathrm{C}$ comprising 46 articles.

The retained articles were then subject to data extraction which was carried out with the use of NVivo software and was guided by the "provisional coding" approach (Miles et al. 2014). The initial set of categories was based on 
TABLE 3 Literature selection process

Literature selection phase Level of analysis $\quad$ Retained articles

Phase A: Initial search

Phase B: Refinement

Phase C: Final selection
Titles, abstracts, keyword lists

Titles and abstracts

Full text
List A: 387 articles

List B: 160 articles

List C: 46 articles

the "CIMO-logic" and included the contexts, the interventions concerning each of the cluster business model elements, the generative mechanisms which stimulated cluster innovativeness and, finally, the cluster innovative outcome. During the coding process, we identified additional sub-categories of codes, notably in relation to the context and generative mechanisms.

We then conducted a descriptive and a "thematic" analysis of the literature. The aim of the former was to provide insight into the contextual characteristics covered in the articles, the authors' understanding of the concept of "cluster innovativeness" and the generative mechanisms triggering it. Finally, during the "thematic" analysis we focused on the six cluster business model elements and distilled the findings of the literature review in the form of design interventions $\left(I_{1} \ldots I_{n}\right)$ aimed at shaping these to foster cluster innovativeness.

\section{Findings}

\subsection{Descriptive Analysis}

To provide a deeper insight into the reviewed literature, we will first describe the findings of our descriptive analysis focusing on the contexts of the studied clusters, the generative mechanisms of cluster innovativeness and the innovation outcomes sought in the reviewed literature. Such an analysis will help understand to what extent the findings of these articles can be generalisable to other contexts.

\subsubsection{Contextual Settings}

Our literature review revealed that the contextual factors influencing cluster innovativeness are multi-scalar and include such dimensions as the national, regional, and sectoral contexts as well as the life-cycle stage and the institutional mode. Most of the reviewed articles ( 41 out of 46) are empirical research papers analysing clusters in a variety of contexts. However, while most reviewed papers provide some basic information into the national, regional and sectoral 
settings of the studied clusters, the majority do not specify the implications of the context for cluster innovativeness.

Concerning the national contexts covered, most papers focused on the European context with 27 papers (or $65 \%$ of the total). Other four articles covered China, three focused on North America, three on Australia and New Zealand, two on Taiwan, while Singapore, Russia, South Africa, Chile, South Korea and the United Arab Emirates each were covered once in separate articles. Only 19 papers provided some insight into the implications of the national context for cluster innovativeness (e.g. Isaksen 2007, Arthurs et al. 2009, Calzonetti et al. 2012, Gebhardt 2013, Gebhardt and Pohlmann 2013, Giest 2015). In most cases, these implications were related to the fact that the studied clusters were supported through targeted cluster or innovation policies of their national governments. Several authors, however, went further in their analysis of the national contexts and mentioned several important factors which may impact cluster design. Specifically, such aspects as the variety of capitalism (Capellin 2003, Isaksen 2007), the level of government involvement (Fromhold-Eisebith and Eisebith 2005, Giest 2015, Ai and Wu 2016, Wei et al. 2016, Huang and Wang 2018), and the broad institutional conditions (Parto 2008, Bek et al. 2013) surfaced as some of the national level factors which may have an impact on cluster innovativeness.

Moreover, although most papers mention the regional characteristics of the studied clusters ( 32 out of 46$)$, they do not provide deeper insight into how these may have influenced the research results. However, 13 papers dive deeper into a discussion of regional characteristics. We have been able to identify two regional factors which may play a role in cluster innovativeness: the preexisting relations between cluster actors (Sellitto and Burgess 2005; Viljamaa 2007; Parto 2008; Eklinder-Frick et al. 2012, 2014; Gretzinger and Royer 2014; Leroux et al. 2014) and the resource endowment defining the historical evolution and orientation of the regional economy (Sellitto and Burgess 2005; Callagher 2012; Calzonetti et al. 2012; Zettinig and Vincze 2012; Basco and Calabrò 2016; Kim and Shim 2018). These papers have shown the importance of a deep understanding of the regional context and demonstrated that there can be no common recipe for success as the pre-existing conditions in each location are unique.

Concerning sectoral specifics of the clusters studied, the papers show great variability, with sectors ranging from high- (13 articles), medium-high and medium-low (11 articles) and low-technology (4 articles) fields, as defined by Eurostat and OECD (Hatzichronoglou 1997; Eurostat 2016). Another 8 articles covered a combination of sectors. Again, only a limited number of studies 
(14 papers) offered a detailed insight into the implications of the sectoral specifics for cluster innovativeness. Two sectoral factors influencing cluster innovativeness emerged from these studies: (1) sectoral knowledge bases defining the key sources of knowledge needed for innovation (Renko et al. 2005, Viljamaa 2007, Burger et al. 2015, Aslesen and Isaksen 2016, Wannenmacher and Antoine 2016, Aslesen and Pettersen 2017) and (2) sectoral trends towards vertical disintegration and collaborative innovation (Fromhold-Eisebith and Eisebith 2005, Burger et al. 2015, Giest 2015, O'Dwyer et al. 2015) or, on the contrary, towards secrecy (Mendel and Bardet 20o9). These studies show that although collaboration is often considered a pre-condition for innovation, it is necessary to understand the dynamics of the sector and the distribution of innovation activities within it to design cluster interactions accordingly. Table 4 provides an overview of the national and sectoral contextual settings covered by the reviewed articles.

TABLE 4 An overview of the national and sectoral contexts covered in the reviewed literature

\begin{tabular}{|c|c|c|c|c|c|}
\hline \multirow{2}{*}{$\begin{array}{l}\text { National } \\
\text { context }\end{array}$} & \multicolumn{5}{|l|}{ Sectoral context } \\
\hline & High-tech & $\begin{array}{l}\text { Medium-high, } \\
\text { medium-low }\end{array}$ & Low-tech & Combination & $\mathrm{N} / \mathrm{a}$ \\
\hline $\begin{array}{l}\text { Europe } \\
\text { (EU, } \\
\text { Norway, UK, } \\
\text { Russia) }\end{array}$ & $\begin{array}{l}\text { (Aliouat \& } \\
\text { Thiaw, 2018; } \\
\text { Burger et al., } \\
\text { 2015; Gebhardt, } \\
\text { 2013; Giest, 2015; } \\
\text { Isaksen, 2007; } \\
\text { Matinheikki } \\
\text { et al., 2017; } \\
\text { Messeni } \\
\text { Petruzzelli et al., } \\
\text { 20o9; O’Dwyer } \\
\text { et al., 2015; Renko } \\
\text { et al., 2005) }\end{array}$ & $\begin{array}{l}\text { (Eklinder-Frick } \\
\text { et al., 2012, } \\
\text { 2014; Fromhold- } \\
\text { Eisebith \& } \\
\text { Eisebith, 2005; } \\
\text { Gretzinger \& } \\
\text { Royer, 2014; } \\
\text { Mendel \& } \\
\text { Bardet, 20o9; } \\
\text { Wannenmacher } \\
\text { \& Antoine, } \\
\text { 2016; Zettinig \& } \\
\text { Vincze, 2012) }\end{array}$ & $\begin{array}{l}\text { (Leroux et al., } \\
2014 ; \text { Scott } \\
\text { et al., 2019) } \\
\text { Total=2 }\end{array}$ & $\begin{array}{l}\text { (Aslesen \& } \\
\text { Isaksen, 2016; } \\
\text { Aslesen \& } \\
\text { Pettersen, } \\
\text { 2017; Castro, } \\
\text { 2015; } \\
\text { Jankowska } \\
\text { et al., 2017; } \\
\text { Klofsten et al., } \\
\text { 2015; Yström } \\
\text { \& Aspenberg, } \\
\text { 2017) }\end{array}$ & $\begin{array}{l}\text { (Bek et al., } \\
\text { 2013; Forest, } \\
\text { 2010; } \\
\text { Gebhardt \& } \\
\text { Pohlmann, } \\
\text { 2013; } \\
\text { Lefebvre, } \\
\text { 2013; } \\
\text { Morgulis- } \\
\text { Yakushev \& } \\
\text { Sölvell, 2017) }\end{array}$ \\
\hline
\end{tabular}


TABLE 4 An overview of the national and sectoral contexts covered in the reviewed literature (cont.)

\begin{tabular}{lll}
$\begin{array}{l}\text { National } \\
\text { context }\end{array}$ & \multicolumn{2}{l}{ Sectoral context } \\
& High-tech & $\begin{array}{l}\text { Medium-high, Low-tech } \\
\text { medium-low }\end{array}$
\end{tabular}

\begin{tabular}{|c|c|c|c|c|c|}
\hline North & (Callagher, 2012; & (Viljamaa, 2007) & (Sellitto \& & (Arthurs & - \\
\hline America, & Giest, 2015) & & Burgess, & et al., 2009; & \\
\hline Australia, & & & 2005) & Calzonetti & \\
\hline New & & & & et al., 2012; & \\
\hline Zealand & & & & $\begin{array}{l}\text { Connell et al., } \\
2014)\end{array}$ & \\
\hline Asia (China, & (Ai \& Wu, 2016; & (Huang \& Wang, & (Kim \& Shim, & (Wei et al., & - \\
\hline Taiwan, & Chiu, 20o9; Giest, & 2018) & 2018) & 2016) & \\
\hline South Korea, & 2015; Zhong \& & & & & \\
\hline Singapore) & Tang, 2018) & & & & \\
\hline Other & - & (Basco \& & - & (Connell & - \\
\hline (Chile, & & Calabrò, 2016) & & et al., 2014; & \\
\hline South & & & & Parto, 2008) & \\
\hline \multicolumn{6}{|l|}{ Africa, } \\
\hline \multicolumn{6}{|l|}{ Egypt, UAE) } \\
\hline $\mathbf{N} / \mathbf{a}$ & - & (Capellin, 2003) & - & - & (Berkowitz, \\
\hline & & & & & 2018 \\
\hline & & & & & Günther \& \\
\hline & & & & & $\begin{array}{l}\text { Meissner, } \\
\text { 2017) }\end{array}$ \\
\hline
\end{tabular}

N.B. SOME ARTICLES COVERED SEVERAL COUNTRIES AND HAVE BEEN MENTIONED IN THE TABLE MORE THAN ONCE. SOME ARTICLES DID NOT FOCUS ON ANY SPECIFIC SECTORAL OR NATIONAL CONTEXT (CONCEPTUAL/THEORETICAL PAPERS AND THE ONES USING QUANTITATIVE METHODS ON A RANGE OF CLUSTERS IN DIFFERENT SECTORS). THESE HAVE BEEN NOTED WITHIN THE 'N/A' COLUMNS.

Finally, two more contextual factors have been covered in the reviewed articles: cluster life-cycle stage and its institutional mode. While 12 articles mentioned the life cycle stage of the studied clusters distinguishing between emergent, developing, stabilising and mature clusters, only four papers provided insight into the cluster life-cycle theory and specified the implications of the life-cycle stage for cluster innovativeness (Arthurs et al. 2009, Callagher 2012, Calzonetti 
et al. 2012, Castro 2015). These suggested that the roles played by the cluster actors as well as the geography and type of knowledge flows and resources needed for cluster innovativeness significantly vary at the different stages of cluster evolution.

Finally, three articles explicitly focused on clusters' institutional modes or the predominance of the private ("bottom-up") vs. public ("top-down") sector actors (Fromhold-Eisebith and Eisebith 2005, Connell et al. 2014, Giest 2015). These suggested that the level of involvement of private and public actors shapes the interests at play, the goals of the cluster actors and the approaches to cluster development.

This analysis shows that a variety of factors influence the propensity of cluster members to innovate and the approaches to innovation these adopt. Some of these are exogenous and relate to the external environment of the cluster: its national, regional and sectoral context. Others are endogenous and pertain to internal conditions specific to the cluster: its life-cycle stage and institutional mode (the level of participation of private and public sector actors). This suggests that no single "one-size-fits-all" approach to fostering cluster innovativeness can be designed and the set of specific interventions and policies should be carefully crafted based on the cluster context.

\subsubsection{Cluster Innovativeness and Its Generative Mechanisms}

Finally, we analysed the approaches to defining and measuring cluster innovativeness in the reviewed literature. Although several authors highlighted the importance of cluster evaluation and performance measurement (e.g. Gebhardt 2013, Giest 2015, Scott et al. 2019), our research shows that innovation performance measurement is an under-developed topic in the cluster field, confirming the general trend in innovation studies (Wolfe 1994, Lupova-Henry and Dotti 2019).

Only 5 articles of the whole set provided a clear conceptualization of "innovation" for their study (Aslesen and Isaksen 2016, Basco and Calabrò 2016, Morgulis-Yakushev and Sölvell 2017, Berkowitz 2018, Kim and Shim 2018), and 11 articles proposed indicators for innovation performance measurement (Sellitto and Burgess 2005, Arthurs et al. 2009, Chiu 2009, Messeni Petruzzelli et al. 2009, Cappellin 2012, Gebhardt and Pohlmann 2013, Giest 2015, Ai and Wu 2016, Basco and Calabrò 2016, Morgulis-Yakushev and Sölvell 2017, Kim and Shim 2018). An important finding from this analysis is the difference in innovation performance indicators for cluster operating in low and medium-low technology fields versus those in high and medium-high technology sectors. For the firms in the former fields, such measures as new product development and continuous improvement and adaptation of existing products and processes 
were mentioned (Capellin 2003, Sellitto and Burgess 2005, Basco and Calabrò 2016, Kim and Shim 2018). On the other hand, to gauge the innovativeness of cluster firms in high and medium-high technology fields the reviewed articles suggest such indicators as $R \& D$ efficiency, time-to-market, successful new product developments (Chiu 2009), R\&D spending, relative innovativeness, new product revenue (Arthurs et al. 2009) as well as patents granted and patent citation (Messeni Petruzzelli et al. 2009). While the aforementioned articles focused on the firm-level innovativeness, Gebhardt and Pohlmann (2013) suggested a set of indicators allowing to evaluate cluster-level innovativeness such as the number of R\&D personnel and science and technology spending, turnover with innovative products, patents, number of publications, and new firm formation in the cluster.

Although the reviewed articles covered a variety of contexts as described above, we found that there is some agreement in the literature as to the generative mechanisms of cluster innovativeness. Most articles ( 28 papers, or $61 \%$ of the total) focused on a set of generative mechanisms which we termed "learning and knowledge". These highlighted the importance of such elements as the external knowledge (Messeni Petruzzelli et al. 2009), the capabilities to explore new knowledge and to exploit the existing sources (Zettinig and Vincze 2012) and absorptive capacities (Giest 2015). The articles referring to this generative mechanism covered a range of sectors, from high-tech ( 8 articles) to medium ( 8 articles) to low technology ( 2 articles), while 7 articles covered a combination of industries.

The second most important group of generative mechanisms in the reviewed literature pertained to "networking and collaboration" with 14 articles. These focused on such aspects as the boundary permeability between the Triple Helix actors (Klofsten et al. 2015), intra-cluster collaboration (Jankowska et al. 2017) as well as cognitive convergence (Aliouat and Thiaw 2018) and actors' network competence (Chiu 2009). Again, the articles are distributed among a variety of sectors with 3 articles covering high-tech fields, 3 articles for medium-tech, 4 papers for low-tech and 3 studies covering a combination of sectors.

Four more papers highlighted the role of sound management and governance in driving cluster innovativeness (Gebhardt 2013, Gebhardt and Pohlmann 2013, Matinheikki et al. 2017, Berkowitz 2018). Finally, two papers focused on other generative mechanisms, such as R\&D (Lefebvre 2013) and current cluster conditions (supporting organisations, cluster factors and competitive environments) (Arthurs et al. 2009).

This analysis shows that cluster contexts need to be carefully considered to devise a relevant set of indicators of firm-level or cluster-level innovativeness. However, several generative mechanisms of cluster innovativeness have been 
found relevant regardless of the innovation outcomes sought or the cluster contexts. This allows formulating a set of interventions which would trigger these generative mechanisms leading to improved cluster innovativeness.

\subsection{Thematic Analysis}

In what follows we will present the findings of our literature review along the six business model dimensions. As the above analysis shows, the reviewed literature covers a very broad range of clusters in different contextual settings. We thus focused on formulating both general interventions - applicable in a variety of settings - and context-specific ones, where it was possible.

\subsubsection{Actors \& Their Roles}

Twenty-four articles out of the total set explicitly focused on the cluster actors and the roles these play in its development. From these studies, two key subthemes emerged:

1. Broadening the scope of cluster actors involved in cluster steering

2. Focusing on the definition, distribution and evolution of the actors' roles First, while some papers focused on the cluster management organisation as a key actor (e.g. Lefebvre 2013, Burger et al. 2015, Giest 2015, Klofsten et al. 2015, Aslesen and Pettersen 2017, Morgulis-Yakushev and Sölvell 2017), most articles highlighted the importance of other actors for cluster steering and facilitation (Viljamaa 2007, Arthurs et al. 2009, Gebhardt and Pohlmann 2013, Castro 2015, Wannenmacher and Antoine 2016, Wei et al. 2016, Günther and Meissner 2017, Huang and Wang 2018, Scott et al. 2019).

The reviewed articles showed that a cluster can be driven by a variety of actors - from universities (Calzonetti et al. 2012) to public bodies (Connell et al. 2014, Zhong and Tang 2018), to individual firm representatives with a high level of network competence (Chiu 20o9). Gebhardt and Pohlmann (2013) show that the capabilities of the actors in charge of cluster management are crucial. To be able to foster cluster innovativeness, actors steering a cluster need to be reflexive, focus on the programmatic design, have general management competences, and decision-making autonomy.

Thus, there is a need to broaden the understanding of "cluster management" and go beyond the activities of the "specialised cluster organisation" to involve other actors such as academia, firms and public bodies. To be successful, however, these need to have the competencies needed to steer such a complex entity. To synthesise, cluster innovativeness can be fostered by:

$\mathrm{I}_{1}$ : Ensuring the participation of various competent cluster actors in cluster management 
The second trend that emerged from the literature is related to the need to distinguish between the different roles actors can play in cluster development and clearly define these (Arthurs et al. 2009, Calzonetti et al. 2012, Eklinder-Frick et al. 2012, Burger et al. 2015, Castro 2015, Klofsten et al. 2015, Matinheikki et al. 2017, Yström and Aspenberg 2017, Scott et al. 2019).

Within this dimension, 7 articles explicitly referred to the Triple Helix approach as a framework explaining the dynamics of interactions of different cluster actors and the distribution of their roles (Viljamaa 2007, Calzonetti et al. 2012, Eklinder-Frick et al. 2012, Klofsten et al. 2015, Günther and Meissner 2017, Yström and Aspenberg 2017, Huang and Wang 2018). Importantly, Calzonetti et al. (2012) indicated that the roles of the Triple Helix actors may differ for medium-high and low technology clusters. Although the role of the university for the medium-high technology cluster fits into the traditional Triple Helix framework (i.e. research, training, technology transfer and incubation), for a low technology cluster, its role is a "developmental" one. This implies liaising with regional and state stakeholders, advancing the cluster through public policy efforts and developing cluster promotion strategies with regional stakeholders (Calzonetti et al. 2012).

This brings us to the second important dimension of the reviewed articles. Thus, our analysis allowed to identify three key roles which different actors may assume in the cluster: facilitators (Eklinder-Frick et al. 2012, Connell et al. 2014, Leroux et al. 2014, Burger et al. 2015, Castro 2015, Giest 2015, Aslesen and Pettersen 2017), sponsors and/or stakeholders (Arthurs et al. 2009, Giest 2015, Berkowitz 2018, Zhong and Tang 2018) as well as visionaries or champions (Klofsten et al. 2015, Wei et al. 2016, Yström and Aspenberg 2017). The facilitation role can include a broad range of activities such as the creation of conditions conducive to knowledge sharing, collective learning, trustand capability-building (e.g. Calzonetti et al. 2012, Lefebvre 2013, Yström and Aspenberg 2017). The sponsor or stakeholder role includes actors providing financial support to the cluster and thus having an influence over its strategic direction and/or external actors holding relevant knowledge for cluster development (Giest 2015, Berkowitz 2018, Scott et al. 2019). Finally, the visionary role - also referred to as a "champion" or "enthusiast" role - is often played by an (informal) leader having high innovation capabilities and a high level of engagement in the cluster activities (Klofsten et al. 2015, Wei et al. 2016, Yström and Aspenberg 2017). These actors are crucial in defining the vision of the cluster and communicating it internally to create cohesion and externally to obtain support for cluster activities. To synthesise these findings, we formulate the following proposition: 
$\mathrm{I}_{2}$ : Identifying actors playing the roles of facilitators, sponsors and/or stakeholders and visionaries

We further identified a range of success factors for each of these roles. Thus, concerning cluster facilitation, the literature highlights the importance of identifying the needs, capabilities and barriers to the innovativeness of cluster actors and adapting the facilitators' approaches accordingly (Lefebvre 2013, Leroux et al. 2014, Klofsten et al. 2015, Basco and Calabrò 2016, Jankowska et al. 2017). Furthermore, to facilitate knowledge flows between different parties, such actors should be able to recognise the differences in their respective language and practices to then be able to alleviate any potential conflicts (Wannenmacher and Antoine 2016). Cluster facilitators should adopt an entrepreneurial approach focusing on market penetration in a pro-active and systematic way, facilitating collective decision-making, and developing competence in both local and global networking (Gebhardt and Pohlmann 2013). Moreover, cluster facilitators need to gain legitimacy and trust of the other cluster actors (e.g. Viljamaa 2007, Leroux et al. 2014, Giest 2015). Finally, literature drawing on the "varieties of capitalism" approach suggests that the facilitation role is more important for the innovativeness of clusters in countries with coordinated market economies (Cappellin 2012). We thus formulate the following design propositions:

$\mathrm{I}_{3}$ : Ensuring that cluster facilitators have a high level of network competence, legitimacy and understanding of actors needs

$\mathrm{I}_{4}$ : Strengthening the cluster facilitation role in the coordinated market economies

Sponsors and stakeholders may comprise both public and private actors or a combination of the two (Connell et al. 2014, Giest 2015, Scott et al. 2019). The inclusion of a broad range of regional stakeholders has been found conducive to cluster innovativeness as it allows to integrate the local knowledge into the cluster's business activities (Berkowitz 2018). Where the main sponsors are cluster members (financing the cluster activities through their fees), the needs and possibilities of smaller companies and start-ups need to be taken into account to ensure a balanced representation of different stakeholders in a cluster (Giest 2015). Furthermore, soliciting financial support of external partners can help to build the cluster's credibility and prestige (Scott et al. 2019). Finally, the involvement of external stakeholders, such as public bodies is more 
important at the early stages of cluster development, where they help promote entrepreneurship and innovation (Huang and Wang 2018). At the later stages, their role should be minimal (Zhong and Tang 2018) and, if present, these should focus on knowledge diffusion and the formation of ties between cluster actors (Huang and Wang 2018).

We thus suggest that cluster innovativeness can be fostered by:

$\mathrm{I}_{5}$ : Ensuring a balanced representation of stakeholders, both internal and external

$\mathrm{I}_{6}$ : Ensuring the support of sponsors and/or stakeholders at early cluster life-cycle stages

Concerning the third type of cluster actors - "enthusiasts" and "visionaries" these should have an entrepreneurial approach, charisma and legitimacy, as well as a vast personal network and a deep understanding of the cluster activities and focus area (Mendel and Bardet 2009, Connell et al. 2014, Klofsten et al. 2015, Yström and Aspenberg 2017, Scott et al. 2019). However, such individuals should also be empowered, have the internally authorised autonomy and be supported in their activities by agents in the periphery who can infuse core members with new knowledge (Klofsten et al. 2015, Scott et al. 2019). The ability of visionaries to lead also depends on power asymmetries in the cluster (Mendel and Bardet 2009, Wei et al. 2016). Thus, the visions and strategic directions of dominant actors are more conducive to cluster innovativeness where these are oriented towards knowledge creation and collaboration (Mendel and Bardet 2009, Burger et al. 2015). However, the role of focal enterprises as champions of cluster development is more important at the early stages of cluster life-cycle (Huang and Wang 2018). To synthesise, we propose the following interventions for innovation-centric cluster design:

$\mathrm{I}_{7}$ : Ensuring that the goals and values promoted by visionaries support the innovation and knowledge-creation orientations

$\mathrm{I}_{8}$ : Strengthening and supporting the visionaries at the early cluster lifecycle stages

\subsubsection{Resources and Capabilities}

In the set of reviewed articles, 33 papers covered the aspect of resources and capabilities needed for cluster innovativeness. Among these, we identified two 
major common themes: the types of resources present in the cluster, and their variety and complementarity.

With respect to the first topic and confirming our preliminary findings, the literature showed that both tangible and intangible resources can be present in a cluster (Fromhold-Eisebith and Eisebith 2005). Several articles focused on the material or "tangible" resources and highlighted the importance of the available finance, talent pool, infrastructure and regional resource endowment (Fromhold-Eisebith and Eisebith 2005, Arthurs et al. 2009, Callagher 2012, Gebhardt 2013, Burger et al. 2015). The majority of articles, however, focused on the "intangible" aspects and identified the following key resources and capabilities influencing cluster innovativeness: social capital (Sellitto and Burgess 2005, Eklinder-Frick et al. 2012, 2014, Gretzinger and Royer 2014, Kim and Shim 2018), network competence (Chiu 2009), collaborative and absorptive capacity (Giest 2015, Aslesen and Pettersen 2017), as well as technological and market capabilities (Renko et al. 2005, Isaksen 2007). The literature showed that insufficient development of tangible or intangible resources and capabilities can impede successful cluster development and limit its innovation potential. We synthesise this into the following design proposition to foster cluster innovativeness:

$\mathrm{I}_{9}$ : Ensuring the balanced development of both tangible and intangible resources

However, different types of tangible and intangible resources may be needed depending on the clusters' exogenous and endogenous contexts. Several studies have drawn attention to the social capital as one of the crucial resources conducive to cluster innovativeness (e.g. Eklinder-Frick et al. 2012, 2014; O'Dwyer et al. 2015; Kim and Shim 2018). However, Eklinder-Frick et al. (2012) show that social capital in a cluster is a multidimensional construct and implies both bonding and bridging forms. The former is associated with a single and cohesive network structure with trust-based relations, while the latter refers to social capital reached through diverse connections and sparse network contacts. Interestingly, these forms of social capital can be shaped by the preexisting regional culture and can have both positive and negative effects on innovation outcomes in clusters (Eklinder-Frick et al. 2012, 2014). We propose the following intervention fostering cluster innovativeness:

$\mathrm{I}_{10}$ : Leveraging the enablers and alleviating the impediments of the preexisting social capital 
Furthermore, to be innovative, cluster actors should have the capabilities to generate, share and utilize knowledge (Isaksen 2007, Forest 2010). In this respect, the building of cluster members' absorptive and collaborative capacity is key for innovation development in clusters (Giest 2015, Aslesen and Pettersen 2017). Other important capabilities include technology orientation and R\&D capabilities in high-technology clusters, as well as the ability to identify problems, understand and research markets or, in other words, the market orientation in both high, medium and low technology fields (Renko et al. 2005, Forest 2010, Ai and Wu 2016, Jankowska et al. 2017, Aliouat and Thiaw 2018). To synthesise, we suggest the following innovation-centric design interventions:

$\mathrm{I}_{11}$ : Ensuring the development of capabilities for knowledge generation, sharing and utilisation

$\mathrm{I}_{12}$ : Ensuring the development of both technology and market orientation in high-tech clusters and focusing on market orientation in lowtech fields

Finally, the variety and complementarity of the resources and capabilities available in the cluster have surfaced as some of the key elements in a range of studies (Mendel and Bardet 2009, Messeni Petruzzelli et al. 2009, Forest 2010, Zettinig and Vincze 2012, Wannenmacher and Antoine 2016, Matinheikki et al. 2017, Aliouat and Thiaw 2018).

While some authors advocate for the need to ensure the variety of resources and capabilities in the cluster as it can allow accessing new types of knowledge and experiences (Forest 2010, Klofsten et al. 2015, Günther and Meissner 2017), other suggest that such a variety can have negative effects. Indeed, it can negatively affect trust, prevent the development of collaborative relationships and may eventually lead to cluster dissipation (Mendel and Bardet 2009, Gebhardt 2013). Involving too great a variety of actors can also lead to difficulty in tailoring the cluster activities to the needs of the members, thus limiting their value (Yström and Aspenberg 2017). On the other hand, excessive similarity should also be avoided as it may lead to increased rivalry (Matinheikki et al. 2017), and be counter-productive for knowledge generation (Forest 2010). Thus, moderate similarity has been found most conducive to cluster innovativeness (Matinheikki et al. 2017).

$\mathrm{I}_{13}$ : Ensuring the moderate similarity of actors' resources and capabilities 
Finally, several authors suggest a range of mechanisms enabling the cluster firms to draw on the resources and capabilities available in the cluster. Thus, Wannenmacher and Antoine (2016) show that a variety of resources may be a pre-requisite for multi-disciplinary cluster projects. In such cases, a peer-mediation process can help enable productive dialogue and knowledge exchange by raising awareness of the different value systems, goals and language of the participants and transcend the barriers between different actor communities (Wannenmacher and Antoine 2016). Moreover, Castro (2015) highlights that the practices of sense-making and sense-giving can be critical in mediating between the different cluster communities. These imply raising awareness of the cluster actors about the added value of knowledge, competences, and the potential of other members. We thus synthesise into the following design intervention for cluster innovativeness:

$\mathrm{I}_{14}$ : Ensuring the awareness of the cluster members of the variety and value of the available resources and capabilities in the cluster

\subsubsection{Value Flows}

While 27 articles in our database focused on the value flows, one article has been found especially relevant for setting the framework for analysing and discussing these. Specifically, Morgulis-Yakushev and Sölvell (2017) identify seven relational channels in a cluster - firm-to-firm, firm-to-research, firmto-education, firm-to-capital, firm-to-public bodies, firm-to-other clusters, firm-to-global - and suggest that value flows between cluster actors can be sub-optimal if the "gaps" exist in these channels. We will now discuss the findings of the other articles through the prism of these seven types of value flows.

Concerning firm-to-firm interactions, the willingness of the cluster members to invest their resources in collective actions and projects is one of the key drivers of clusters' collective innovativeness (Matinheikki et al. 2017). Maintaining connectivity between member firms is one of the major priorities for mature clusters to ensure continuous knowledge flows as the number of members grows (Connell et al. 2014). Furthermore, firm-to-firm interactions are more relevant for less R\&D-intensive industries relying on innovations developed through problem-solving by companies and drawing upon applied research and learning through interactions with customers and suppliers, i.e. the "synthetic" knowledge base (Calzonetti et al. 2012, Cappellin 2012, Aslesen and Isaksen 2016). We synthesise this into the following innovation-centric design propositions: 
$\mathrm{I}_{15}$ : Ensuring that cluster actors are willing to engage in firm-to-firm interactions and share both tangible and intangible resources

$\mathrm{I}_{16}$ : Focusing on maintaining firm-to-firm connectivity and knowledge flows in mature clusters and those relying on the "synthetic" knowledge base

The relevance of firm-to-research and firm-to-education depends on the knowledge base the cluster firms draw upon in their innovation activities (e.g. Calzonetti et al. 2012, Aslesen and Isaksen 2016, Aslesen and Pettersen 2017). Thus, firms operating in high-tech, R\&D-intensive, industries draw upon fundamental research - or "analytic" knowledge base - and are more likely to perform in-house R\&D and engage with universities and research centres conducting fundamental research (Calzonetti et al. 2012, Aslesen and Isaksen 2016). Moreover, the importance of firm-to-education and firm-to-research connections has been found more important at the early cluster life-cycle stages as well as at "transformation" stages, which occur when the current dominant technological paradigms are exhausted, and new sources of opportunities are needed (Viljamaa 2007). Relations with the academia may be transformed from the generative (new venture creation and technology development) to developmental once the cluster reaches a more stable trajectory and is able to sustain the momentum itself. In this case, relationships with the university may help the cluster build its brand and image, reach new markets and gain recognition at the regional and national levels (Calzonetti et al. 2012). On the other hand, in clusters operating in less technologically sophisticated sectors of activity, the relationships with academia may also matter, however, they are likely to draw less on the Triple Helix interaction model (Calzonetti et al. 2012). Indeed, in such clusters, links with academia may prove to be more valuable in terms of building social capital and developing cluster brand and image as well as its representation nationally and internationally (Calzonetti et al. 2012). We thus propose the following interventions improving cluster innovativeness:

$\mathrm{I}_{17}$ : Ensuring firm-to-(fundamental) research connectivity for clusters operating in sectors drawing on "analytic" knowledge bases

$\mathrm{I}_{18}$ : Ensuring firm-to-(applied) research connectivity for clusters operating in sectors drawing on "synthetic" knowledge bases

$\mathrm{I}_{19}$ : Ensuring and strengthening firm-to-research and firm-to-education connections at the formation and "transformation" cluster life-cycle stages 
Firm-to-capital relations have been found important, especially, for SME clusters having limited resources (Renko et al. 2005). Foreign direct investment attraction - often considered an efficient way to finance regional development - has been found a controversial approach (Burger et al. 2015, O'Dwyer et al. 2015). Indeed, it is necessary to distinguish between two types of MNC subsidiary activities: low-value-added activities such as production plants and sales and marketing offices, and high-value-added business functions, such as R\&D and education (Burger et al. 2015). While most clusters succeed in attracting low-value-added investments, these do not have a significant effect on the innovativeness of local firms (Burger et al. 2015). On the other hand, for high-value-added investments, it is necessary to develop the appropriate specialised location factors, such as unique and "sticky" knowledge in the cluster, the pool of high-skilled workers and high-tech culture (Isaksen 2007, Burger et al. 2015). We synthesise into the following innovation-centric design interventions:

$\mathrm{I}_{20}$ : Distinguishing between low- and high-value-added foreign direct investments and focusing on the latter

Concerning firm-to-other-clusters and firm-to-global interactions, being able to tap into regional, national and extra-national (global) sources of knowledge has been found an important driver of cluster innovativeness (Isaksen 2007, Messeni Petruzzelli et al. 2009, Ai and Wu 2016, Wei et al. 2016). These value flows can be even more important where the regional resource endowment is not sufficient for innovation (Callagher 2012). For instance, international public and private donors and international powerful actors can be important for the development of clusters in developing countries with weak institutions (Parto 2008).

Such outreach, however, necessitates cognitive, organisational and institutional proximity between the actors, i.e. respectively a common knowledge base, formal organisational structures (e.g. strategic alliances, mergers and acquisitions) and a joint understanding of what is needed to achieve competitiveness (Isaksen 2007, Messeni Petruzzelli et al. 2009). Moreover, the relevance of inter-regional or inter-national connections depends on the geographical distribution of innovation activities in the sector (Ai and $\mathrm{Wu} 2016$ ). For instance, in the countries where major R\&D capacities lie with nationlevel organisations, the cluster actors rely on these for the building of their innovation capacities (Isaksen 2007). Furthermore, the relevance of external connections is higher for companies drawing on fundamental research and R\&D ("analytic" knowledge bases) as these represent codifiable, i.e. less 
geographically-bound knowledge (Aslesen and Isaksen 2016). To synthesise, we suggest the following interventions conducive to cluster innovativeness:

$\mathrm{I}_{21}$ : Establishing external links with cognitively, organisationally, or institutionally proximate actors

$\mathrm{I}_{22}$ : Establishing external connections with the major sources of innovation in the sector

$\mathrm{I}_{23}$ : Establishing external connections allowing to compensate for the lack of regional or national resource endowment

Several articles have highlighted the importance of virtual communication and bidding platforms and marketplaces as some of the tools facilitating knowledge flows between cluster actors and contributing to their innovativeness (e.g. Sellitto and Burgess 2005, Gebhardt and Pohlmann 2013, Zhong and Tang 2018). Such tools, however, are more effective where relationships between cluster actors already exist as they contribute to strengthening these ties rather than establishing them (e.g. Sellitto and Burgess 2005). Finally, balancing weak and strong ties - or knowledge exploration and exploitation relations respectively - is crucial and requires the cluster as a whole to remain adaptive to external change and to create and re-create routines allowing it to repeatedly reap the benefits form the value it generates (Zettinig and Vincze 2012). Synthesising these findings, we propose the following innovation-centric design interventions:

$\mathrm{I}_{24}$ : Establishing virtual platforms facilitating knowledge flows

$\mathrm{I}_{25}$ : Balancing ties allowing the exploitation of the available opportunities and the exploration of new ones

\subsubsection{Governance}

Twenty-two of the reviewed articles covered the subject of governance. Confirming our preliminary findings, the reviewed literature distinguishes between formal and informal governance mechanisms in clusters (e.g. Isaksen 2007, Cappellin 2012, Gretzinger and Royer 2014, Wei et al. 2016). Although the informal governance mechanisms - such as unwritten agreements and trustbased relations - are important, over-reliance on these can prevent the cluster from developing a goal-oriented formal structure, the absence of which can be a barrier to creating partnerships and building social capital (Gretzinger 
and Royer 2014). Moreover, structured organisational arrangements have been found more conducive to trust-building and knowledge flows between the parties than ad hoc arrangements (Connell et al. 2014). Formal rules for leadership and collaboration should be transparent (Gebhardt 2013) and governance should be based on negotiations and agreements (Cappellin 2012). Thus, a balance between formal and informal governance mechanisms should be established for a cluster to be innovative, where formal contracts are used along with unwritten agreements (Isaksen 2007, Wei et al. 2016). This is particularly relevant for clusters in unsupportive institutional settings, e.g. lacking the protection of property rights, where these may act as "safe environments" if appropriate governance mechanisms are devised (Bek et al. 2013). We synthesise these findings into the following design propositions to foster cluster innovativeness:

$I_{26}$ : Balancing formal and informal governance mechanisms

$\mathrm{I}_{27}$ : Ensuring the governance mechanisms provide a "safe environment" for clusters operating in unsupportive contexts

Furthermore, where the public bodies play an important role in cluster governance, effort should be made to establish transparent communication and governance structures so that the public authorities and the clusters' selfregulatory bodies are well-connected and aware of each other's goals, needs and priorities (Parto 2008, Wei et al. 2016). We synthesise into the following innovation-centric design intervention:

$\mathrm{I}_{28}$ : Ensuring the connectedness and transparent communication between public and private sector cluster actors

Given the complexity of the network relations in the cluster, where actors have different motivations and goals (for example, market value creation versus knowledge creation), multi-level formal governance mechanisms are needed (Scott et al. 2019). Specifically, an overarching governance board and a master agreement should co-exist with more specific governance arrangements suited to the needs of individual actors and projects (Scott et al. 2019). A feasible and clear strategy is crucial, however, and cluster actors should identify with it as such commitment contributes to more robust management and facilitates conflict settlement (Gebhardt 2013). Moreover, the actors involved in cluster governance can be viewed as important resources and pools of knowledge and cluster governance structures should be reflexive, adaptive and "porous", 
allowing to absorb new knowledge (Castro 2015). We propose the following set of interventions to enhance cluster innovativeness:

$\mathrm{I}_{29}$ : Ensuring the participation and commitment of different cluster actors in its governance

$\mathrm{I}_{30}$ : Establishing adaptive and "porous" governance arrangements facilitating the absorption of new knowledge

$\mathrm{I}_{31}$ : Establishing multi-level governance arrangements

\subsubsection{Value Proposition}

The subject of cluster value proposition was covered by 9 articles. In line with our preliminary findings, the reviewed literature distinguishes between value created for clusters' external stakeholders, i.e. contributing to regional development, and for its internal actors, i.e. enhancing the competitiveness of their members and contributing to their financial and non-financial performance (Klofsten et al. 2015, O'Dwyer et al. 2015, Matinheikki et al. 2017). A clearly defined and viable external value proposition or "idea" of a cluster originating in a real market need has been found one of its key success factors (Klofsten et al. 2015). We propose the following intervention for innovation-centric cluster design:

$\mathrm{I}_{32}$ : Clearly defining a viable external value proposition based on a real market need

However, internal and external value propositions are inter-related: the presence of a clearly-articulated system-level goal (external value proposition) offers a sense of community to cluster members, improves their participation and willingness to share resources (internal value proposition) (Klofsten et al. 2015, Matinheikki et al. 2017). Successful innovation-centric clusters can identify with nation-wide economic development goals and contribute to these at the same time presenting important opportunities for learning and knowledge-sharing for the participants (O'Dwyer et al. 2015). Indeed, the motivation for individual members to participate in a cluster can be both externally-motivated - for instance, by the desire to contribute to nation-wide development of the knowledge economy - and internally-driven by the need to find new, innovation-based, sources of competitive advantage (O'Dwyer et al. 2015). We thus propose the following innovation-centric design interventions: 
$\mathrm{I}_{33}$ : Aligning the external goals with the motivations, capabilities and goals of individual members

$\mathrm{I}_{34}$ : Identifying with broader national or regional development priorities

\subsubsection{Value-Creating Activities}

Twenty articles in our selection focused on value-creating activities. These fell within the four groups of previously identified innovation-related activities in a meta-organisational setting: the orchestration of knowledge capabilities, ongoing strategizing, developing public policy and theorising innovation (Dougherty and Dunne 2011, Gimet and Grenier 2018). However, we also identified an additional category, the "generative" activities, i.e. the generation or provision of resources needed for cluster development, such as scientific knowledge, talent and university spin-offs (Calzonetti et al. 2012). This type of activity, however, has been found more relevant for high-technology, than medium-technology clusters (Calzonetti et al. 2012). We synthesise these findings into the following propositions for innovation-centric cluster design:

$\mathrm{I}_{35}$ : Engaging in five innovation-related activities: the orchestration of knowledge capabilities, ongoing strategizing, developing public policy, theorising innovation and resource generation

$\mathrm{I}_{36}$ : Focusing on the "generative" activities in high-technology clusters

Concerning the orchestration of knowledge capabilities, it includes activities that aim to create, share and combine knowledge (Castro 2015). Yström and Aspenberg (2017) refer to these activities as enabling cluster actors to act in a collaborative space by forging relationships, facilitating projects and offering a forum for sharing knowledge. Other articles noted such activities as the development of capabilities for learning and knowledge-sharing as well as searching for innovation opportunities (e.g. organising peer-learning groups, fairs and trade missions as well as networking events) (Lefebvre 2013, Connell et al. 2014). We thus suggest that cluster innovativeness can be enhanced by:

$\mathrm{I}_{37}$ : Orchestrating knowledge capabilities with respect to the knowledge bases and innovation modes of cluster actors

Ongoing strategizing refers to cluster's ability to position itself, formalise its structure and goals (Gretzinger and Royer 2014), be adaptive and reflexive 
(Castro 2015) and involve a wide range of stakeholders to integrate local knowledge (Berkowitz 2018). Developing public policy as well as regional networking have been found some of the key "developmental" activities of cluster actors especially relevant for medium-technology clusters (Calzonetti et al. 2012). We formulate the following design proposition conducive to cluster innovativeness:

$\mathrm{I}_{38}$ : Focusing on public policy development activities in mediumtechnology clusters

Concerning "theorising innovation", Yström and Aspenberg (2017) refer to "narration" activities of cluster actors implying storytelling and agenda-setting practices to forge cluster identity and foster a sense of membership (Yström and Aspenberg 2017). Developing cluster identity, international visibility and brand-building has been commonly highlighted in the literature as crucial activities for the development of cluster image, attracting members and external funds (e.g. Gebhardt 2013, Connell et al. 2014, Morgulis-Yakushev and Sölvell 2017). These activities, however, may be more relevant for clusters at the formation and "transformation" stages (e.g. Ingstrup and Damgaard 2013, Connell et al. 2014, O'Dwyer et al. 2015). We synthesise these findings into the following design proposition for cluster innovativeness:

$\mathrm{I}_{39}$ : Focusing on "theorising innovation" activities for agenda-setting and brand-building at the formation and "transformation" stages of cluster development

\section{5}

\section{Discussion and Conclusions}

In this article, we set out to explore the premises of the innovation-centric cluster design by taking stock of the extant research in this field. We adopted the business model lens to identify cluster elements which, if shaped appropriately, can produce the desired results. We identified six cluster business model elements: actors and their roles, resources and capabilities, value flows, governance, value propositions and value-creating activities.

Our goal was two-fold: to both advance our understanding of the value creation in "managed" clusters seen here as "meta-organisations" and pave the way for evidence-based management in these. We thus adopted the design orientation in this paper and applied the "CIMO" framework (Denyer et al. 2008) throughout the article. We thus analysed the Contexts covered in the reviewed 
articles, innovation outcomes sought and generative mechanisms triggering these. We then distilled the findings of our literature review in the form of interventions for the innovation-centric design of a cluster business model. In line with the design-science approach, we suggest using these interventions "as input to the creative and innovative process of designing" rather than "a set of instructions or fixed protocols" (van Aken and Romme 2012: 43).

Four important insights and further research paths emerged from our literature review. First, we identified the lack of a systematic approach to the analysis of exogenous factors and their influence on cluster innovativeness. Although some articles provided insights into the contextual influences by focusing on the national (e.g. Cappellin 2012, Bek et al. 2013), regional (e.g. Eklinder-Frick et al. 2012, 2014) or sectoral (e.g. Calzonetti et al. 2012, Aslesen and Isaksen 2016) specifics, none of these investigated the interplay between the three scales. Thus, the call for a multi-scalar approach in innovation studies voiced by Bunnell and Coe (2001) still goes largely unanswered in the field of cluster research which suggests an interesting path for future studies. These could explore the cluster-environment relations building upon the literature analysing organisation, strategy and environment interactions (e.g. Chakravarthy 1982, Jennings and Seaman 1994, Volberda et al. 2012). For instance, it may be interesting and worthwhile to explore whether and how clusters design their business model to fit their environment and if this helps them achieve better innovation performance. Furthermore, interesting insights into cluster strategy and structure may emerge from comparative studies applying the business model framework to clusters at different life-cycle stages, having different institutional modes and operating in different national, regional, and industrial contexts. Such studies could draw upon the "comparative institutionalism" perspective in organisation studies (e.g. Jackson and Deeg 2006, Hotho and Saka-Helmhout 2017).

Second, a careful reading of the articles shows that there is a confusion in the cluster studies between the various concepts of clusters, technoparks or Science Parks and innovation networks. In some cases, these are used interchangeably (e.g. Capellin 2003, Ai and Wu 2016, Zhong and Tang 2018), while some articles see clusters as parts of science parks (Chiu 2009). Such inconsistent use of the terminology may be misleading. Indeed, some researchers have suggested that clear differences may be drawn between the various forms of the spatial organisation of innovation activities including science parks, clusters, and networks (e.g. Rosenfeld 1997). To bring more conceptual clarity to the field, we see a potential for the application of the "meta-organisational" perspective to refer to the organised forms of collaboration, such as managed clusters, managed science parks or managed networks. This approach has 
been adopted by several articles in our literature review (Matinheikki et al. 2017, Berkowitz 2018). The umbrella term of "meta-organisation" may also be valuable in highlighting the crucial differences between the organised and non-organised forms of clustering. The extension of the meta-organisational approach to other forms of collaborative arrangements such as science parks, technoparks and innovation networks calls for further theoretical and empirical investigations of these forms of organising to allow drawing parallels with the meta-organisational research. This may be a fruitful undertaking for future studies in this field.

Third, analysing the literature through the prism of six cluster business model elements we were able to gain a detailed insight into each of these elements thus extending the meta-organisational research. Notably, we have been able to identify three major roles played by the cluster actors: facilitators, sponsors and/or stakeholders and visionaries. Contrary to the mainstream cluster studies, our findings suggest that cluster facilitation role is not reserved to any single actor (such as a dedicated "cluster management organisation") and can be played by other actors, such as academia, labour unions and individual companies. Our research confirmed the presence of tangible and intangible cluster resources and capabilities and related value flows and highlighted the importance of the intangible ones for innovation. We also found support for the importance of both formal and informal governance mechanisms for cluster innovativeness. Concerning cluster value propositions, our research confirmed its multi-dimensional nature, whereby both internal and external value propositions are critical for cluster innovativeness. Finally, we found that cluster studies support the relevance of the four previously identified innovationrelated activities but also identify the fifth type of activities: generative, i.e. the generation and provision of resources relevant for cluster development. Thus, by identifying the elements of a cluster business model, we made the groundwork for future research which could focus on different configurations of these to identify different types of clusters with relation to their strategy-making. Such research could draw inspiration from the configurational approach to strategy (cf. Meyer et al. 1993).

Finally, we identified a lack of a systematic approach to measuring or, at the very least, defining cluster innovativeness. Although this is partly explained by the predominance of qualitative approaches in the reviewed articles, this limits the development of a more holistic understanding of the outcomes clusters are expected to deliver.

Our study is, of course, not without its limitations. First, by choosing to focus exclusively on academic articles, we excluded "grey" literature, such as reports 
by specialised cluster organisations or policymakers which, potentially, could provide additional insights. This, however, can be explored in future studies that may take a broader stance and analyse "grey" literature as well.

\section{References}

Adner R (2006) Match your innovation strategy to your innovation ecosystem. Harvard Business Review 84: 98-107; 148.

Adner R and Kapoor R (2010) Value creation in innovation ecosystems: How the structure of technological interdependence affects firm performance in new technology generations. Strategic Management Journal 31: 306-333.

Ahrne G and Brunsson N (2005) Organizations and meta-organizations. Scandinavian Journal of Management 21: 429-449.

Ahrne G and Brunsson N (2008) Meta-Organizations. Cheltenham: Edward Elgar Publishing.

Ai C-H and Wu H-C (2016) Where does the source of external knowledge come from? A case of the Shanghai ICT chip industrial cluster in China.Journal of Organizational Change Management 29(2):150-175.

van Aken JE and Romme ALG (2009) Reinventing the future: adding design science to the repertoire of organization and management studies. Organization Management Journal 6: 5-12.

van Aken JE and Romme ALG (2012) A design science approach to evidence-based management. In: Rousseau D (ed.) The Oxford Handbook of Evidence-Based Management. Oxford: Oxford University Press.

Aliouat B and Thiaw CAL (2018) Communauté épistémique et dynamique d'innovation collaborative : l'innovation contrariée au sein des pôles de compétitivité. Communication Management 15:35-59.

Allee V (2000) Reconfiguring the value network. Journal of Business Strategy 21: $36-39$.

Amit R and Zott C (2001) Value creation in e-business. Strategic Management Journal 22: 493-520.

Arend RJ (2013) The business model: present and future - beyond a skeumorph. Strategic Organization 11: 390-402.

Arthurs D, Cassidy E, Davis CH and Wolfe D (2009) Indicators to support innovation cluster policy. International Journal of Technology Management 46: 263-279.

Aslesen HW and Isaksen A (2016) Clusters initiatives, open innovation and knowledge bases. In: Shearmur R, Carrincazeaux C and Doloreux D (eds) Handbook on the Geographies of Innovation. Cheltenham: Edward Elgar Publishing, 155-168. 
Aslesen HW and Pettersen IB (2017) Entrepreneurial firms in STI and DUI mode clusters: do they need differentiated cluster facilitation? European Planning Studies 25: 904-922.

Aydalot P (1986) Milieux innovateurs en Europe. GREMI, Paris.

Azzam JE and Berkowitz H (2018) Patterns of coopetition in meta-organizations. In: Fernandez A-S, Chiambaretto P, Le Roy F and Czakon W (eds) Routledge Companion to Coopetition Strategies. London: Routledge, 280-291.

Baden-Fuller C and Morgan MS (2010) Business models as models. Long Range Planning 43: 156-171.

Bankvall L, Dubois A and Lind F (2017) Conceptualizing business models in industrial networks. Industrial Marketing Management 6o: 196-203.

Basco R and Calabrò A (2016) Open Innovation Search Strategies in Family and NonFamily SMEs. Academia Revista Latinoamericana de Administración.

Becattini G (1987) Mercato e forze locali: il distretto industriale. Bologna: il Mulino.

Becattini G (1989) Riflessioni sul distretto industriale marshalliano come concetto socio-economico. Stato e mercato: 111-128.

Bek MA, Bek NN, Sheresheva MY and Johnston WJ (2013) Perspectives of SME innovation clusters development in Russia. Journal of Business \& Industrial Marketing 28(3): 240-259.

Berkowitz H (2018) Meta-organizing firms' capabilities for sustainable innovation: a conceptual framework. Journal of Cleaner Production 175: 420-430.

Berkowitz H and Dumez H (2016) The concept of meta-organization: issues for management studies. European Management Review 13: 149-156.

Berkowitz H and Bor S (2018) Why meta-organizations matter: a response to Lawton et al. and Spillman. Journal of Management Inquiry 27: 204-211.

Brès L, Raufflet E and Boghossian J (2018) Pluralism in organizations: learning from unconventional forms of organizations. International Journal of Management Reviews 20: 364-386.

Breschi S and Malerba F (1997) Sectoral innovation systems: technological regimes, Schumpeterian dynamics, and spatial boundaries. In: Edquist C (ed.) Systems of Innovation: Technologies, Institutions and Organizations. London: Pinter/Cassell, 130-156.

Briner RB and Denyer D (2012) Systematic review and evidence synthesis as a practice and scholarship tool. In: The Oxford Handbook of Evidence-Based Management, $112-129$.

Bunnell TG and Coe NM (2001) Spaces and scales of innovation. Progress in Human Geography 25: 569-589.

Burger MJ, Karreman B and van Eenennaam F (2015) The competitive advantage of clusters: Cluster organisations and greenfield FDI in the European life sciences industry. Geoforum 65: 179-191. 
Callagher L (2012) Searching near and far: a practice perspective of knowledge access in emerging clusters. International Journal of Entrepreneurship and Innovation Management 15 .

Calzonetti FJ, Miller DM and Reid N (2012) Building both technology-intensive and technology-limited clusters by emerging research universities: the Toledo example. Applied Geography 34: 265-273.

Camagni RP (1995) The concept of innovative milieu and its relevance for public policies in European lagging regions. Papers in Regional Science 74: 317-340.

Cappellin R (2003) Networks and technological change in regional clusters. In: Bröcker J, Dohse D and Soltwedel R (eds) Innovation Clusters and Interregional Competition. Berlin, Heidelberg: Springer Verlag, $5^{2-78}$.

Cappellin R (2012) Knowledge creation and innovation in medium technology clusters. In: Bo C, Chatterji M and Chaoyan H (eds) Contributions to Conflict Management, Peace Economics and Development 20. Bingley, UK: Emerald Group Publishing Limited, $185^{-216 .}$

Castells M (1996) The rise of the network society. In: Castells M, The Information Age: Economy, Society, and Culture (second edition). Oxford: Blackwell.

Castells M and Hall P (1994) Technopoles of the World: The Making of 21st Century Industrial Complexes. London: Routledge.

Castro L (2015) Strategizing across boundaries: revisiting knowledge brokering activities in French innovation clusters. Journal of Knowledge Management 19(5).

Chakravarthy BS (1982) Adaptation: a promising metaphor for strategic management. The Academy of Management Review 7: 35-44.

Chesbrough H (2007) Why companies should have open business models. MIT Sloan Management Review 48: 22.

Chesbrough H, Van Haverbeke W and West J (eds) (2006) Open Innovation: Researching a New Paradigm. Oxford: Oxford University Press.

Chiu YTH (2009) How network competence and network location influence innovation performance. Journal of Business \& Industrial Marketing 24(1). DoI: $10.1108 / 08858620910923694$.

Coletti M and Di Maria E (2015) The rush for cluster initiatives: cluster organization and management in Central Europe. International Journal of Entrepreneurship and Innovation Management 19: 327-342.

Connell J, Kriz A and Thorpe M (2014) Industry clusters: an antidote for knowledge sharing and collaborative innovation? Journal of Knowledge Management 18: 137-151.

Cooke P, Gomez Uranga M and Etxebarria G (1997) Regional innovation systems: institutional and organisational dimensions. Research Policy 26: 475-491.

Denyer D and Tranfield D (2006) Using qualitative research synthesis to build an actionable knowledge base. Management Decision 44: 213-227. 
Denyer D, Tranfield D, and van Aken JE (2008) Developing design propositions through research synthesis. Organization Studies 29: 393-413.

Dougherty D and Dunne DD (2011) Organizing ecologies of complex innovation. Organization Science 22: 1214-1223.

Edquist C (1997) Systems of Innovation: Technologies, Institutions, and Organizations. London: Pinter/Cassell.

Eklinder-Frick J, Eriksson LT and Hallén L (2012) Effects of social capital on processes in a regional strategic network. Industrial Marketing Management 41: 80o-8o6.

Eklinder-Frick J, Eriksson LT and Hallén L (2014) Multidimensional social capital as a boost or a bar to innovativeness. Industrial Marketing Management 43: 46o-472.

Etzkowitz H (1993) Enterprises from science: the origins of science-based regional economic development. Minerva 31: 326-36o.

Etzkowitz H (2002) Networks of innovation: science, technology and development in the triple helix era. International Journal of Technology Management \& Sustainable Development 1: 7-20.

Etzkowitz H (2012) Triple Helix Clusters: Boundary Permeability at University Industry - Government Interfaces as a Regional Innovation Strategy. Environment and Planning C: Government and Policy 30: 766-779.

Etzkowitz H and Leydesdorff L (1995) The Triple Helix - University-Industry-Government Relations: A Laboratory for Knowledge Based Economic Development. Rochester, NY: Social Science Research Network.

Etzkowitz $\mathrm{H}$ and Klofsten M (2005) The innovating region: toward a theory of knowledge-based regional development. $R \& D$ Management 35: 243-255.

European Innovation Monitoring System (EIMS) (1993) Public Measures to Support the Clustering and Network of Innovative SMEs. Luxembourg: EIMS.

Eurostat (2016) Glossaire: classification des industries manufacturières de haute technologie - statistics explained. Available at: http:/ec.europa.eu/eurostat/ statistics-explained/index.php/Glossary:High-tech_classification_of_manufacturing _industries/fr.

Fjeldstad ØD and Snow CC (2018) Business models and organization design. Long Range Planning 51: 32-39.

Forest J (2010) La production de connaissances a l'ère des pôles de compétitivité. Innovations 32: 129-146.

Fromhold-Eisebith M and Eisebith G (2005) How to institutionalize innovative clusters? Comparing explicit top-down and implicit bottom-up approaches. Research Policy 34: 1250-1268.

Gadille M, Tremblay D-G and Vion A (2013) La méta-organisation territorialisée, moteur d'apprentissages collectifs. Revue Interventions économiques. Papers in Political Economy. 
Gebhardt C (2013) The making of plasma medicine. Strategy driven clusters and the emerging roles of cluster management and government supervision. The Journal of Technology Transfer 38: 401-414.

Gebhardt C and Pohlmann MC (2013) Managing the organisation 2.o: Entrepreneurial spirit and general management competences as early indicators for cluster success and sustainable regional development: findings from the German entrepreneurial regions programme. The Journal of High Technology Management Research 24: 153-16o.

Giest S (2015) Network capacity-building in high-tech sectors: opening the black box of cluster facilitation policy. Public Administration 93: 471-489.

Gimet P and Grenier C (2018) Gouvernance et leadership d'une méta-organisation innovante: Le cas d'un pôle dédié aux services médicosociaux à domicile. Revue française de gestion 44: 11-27.

Gretzinger S and Royer S (2014) Relational resources in value adding webs: the case of a Southern Danish firm cluster. European Management Journal 32: 117-131.

Gulati R, Puranam P and Tushman M (2012) Meta-organization design: rethinking design in interorganizational and community contexts. Strategic Management Journal 33: 571-586.

Günther J and Meissner D (2017) Clusters as innovative melting pots? The meaning of cluster management for knowledge diffusion in clusters. Journal of the Knowledge Economy 8: 499-512.

Hatzichronoglou T (1997) Revision of the High-Technology Sector and Product Classification. Paris: OECD. DOI: https://doi.org/10.1787/134337307632.

Hospers G-J, Desrochers P and Sautet F (2009) The next Silicon Valley? On the relationship between geographical clustering and public policy. International Entrepreneurship and Management Journal 5: 285-299.

Hotho J and Saka-Helmhout A (2017) In and between societies: reconnecting comparative institutionalism and organization theory. Organization Studies 38: 647-666.

Huang C and Wang Y (2018) Evolution of network relations, enterprise learning, and cluster innovation networks: the case of the Yuyao plastics industry cluster. Technology Analysis \& Strategic Management 30: 158-171.

Iansiti M and Levien R (2004) The Keystone Advantage: What the New Dynamics of Business Ecosystems Mean for Strategy, Innovation, and Sustainability. Boston, MA: Harvard Business School Publishing.

Ingstrup MB (2010) The role of cluster facilitators. International Journal of Globalisation and Small Business 4: 25-40.

Ingstrup MB and Damgaard T (2013) Cluster facilitation from a cluster life cycle perspective. European Planning Studies 21: 556-574.

Isaksen A (2007) Clusters, innovation and the local learning paradox. Int. J. Entrepreneurship and Innovation Management 7: 366-384. 
Jackson G and Deeg R (2006) How Many Varieties of Capitalism? Comparing the Comparative Institutional Analyses of Capitalist Diversity. Rochester, NY: Social Science Research Network.

Jankowska B, Götz M and Główka C (2017) Intra-cluster cooperation enhancing SMEs' competitiveness - The role of cluster organisations in Poland. Investigaciones Regionales 195-214.

Jarzabkowski P and Fenton E (2006) Strategizing and organizing in pluralistic contexts. Long Range Planning 39: 631-648.

Jennings DF and Seaman SL (1994) High and low levels of organizational adaptation: an empirical analysis of strategy, structure, and performance. Strategic Management Journal 15: 459-475.

Jones $\mathrm{O}$ and Gatrell C (2014) Editorial: the future of writing and reviewing for IJMR. International Journal of Management Reviews 16: 249-264.

Ketels C, Lindqvist G and Sölvell Ö (2006) Cluster Initiatives in Developing and Transition Economies. Center for Strategy and Competitiveness, Stockholm.

Kim N and Shim C (2018) Social capital, knowledge sharing and innovation of small- and medium-sized enterprises in a tourism cluster. International Journal of Contemporary Hospitality Management 30: 2417-2437.

King BG, Felin T and Whetten DA (2010) Perspective - finding the organization in organizational theory: a meta-theory of the organization as a social actor. Organization Science 21: 290-305.

Klofsten M, Bienkowska D, Laur I and Sölvell I (2015) Success factors in cluster initiative management: mapping out the "big five". Industry and Higher Education 29: $65^{-77}$.

Lefebvre P (2013) Organising deliberate innovation in knowledge clusters: from accidental brokering to purposeful brokering processes. International Journal of Technology Management 63: 212-243.

Leroux I, Muller P, Plottu B and Widehem C (2014) Innovation ouverte et évolution des business models dans les pôles de compétitivité : le rôle des intermédiaires dans la création variétale végétale. Revue d'économie industrielle: $115^{-151}$.

Leydesdorff L and Ivanova I (2016) "Open innovation" and "triple helix" models of innovation: can synergy in innovation systems be measured? Journal of Open Innovation: Technology, Market, and Complexity 2.

Leys V and Joffre P (2014) Méta-organisations et évolution des pratiques managériales. Une étude appliquée au champ de la santé. Revue française de gestion 40: 121-134.

Lindqvist G, Ketels C and Sölvell Ö (2013) The Cluster Initiative Greenbook 2.o. Stockholm: Ivory Tower Publishers.

Lundvall B-Å (1992) National Systems of Innovation: Towards a Theory of Innovation and Interactive Learning. London: Pinter Publishers. 
Lupova-Henry E and Dotti NF (2019) Governance of sustainable innovation: moving beyond the hierarchy-market-network trichotomy? A systematic literature review using the "who-how-what" framework. Journal of Cleaner Production 210: 738-748.

Lupova-Henry E, Blili S and Dal Zotto C (2019) Do Clusters Act? Understanding Clusters' Ability to Change Their Environment. University of Neuchâtel, Neuchâtel, Switzerland.

Lusch RF, Vargo SL and Tanniru M (2010) Service, value networks and learning. Journal of the Academy of Marketing Science 38: 19-31.

Markides CC (2013) Business model innovation: what can the ambidexterity literature teach us? Academy of Management Perspectives 27: 313-323.

Marshall A (1890) The Principles of Economics. Basingstoke and New York: Palgrave Macmillan.

Matinheikki J, Pesonen T, Artto K and Peltokorpi A (2017) New value creation in business networks: The role of collective action in constructing system-level goals. Industrial Marketing Management 67: 122-133.

Mendel A and Bardet M (2009) Quelle gouvernance pour les pôles de compétitivité constitués de PME? Revue française de gestion: 123-142.

Messeni Petruzzelli A, Albino V and Carbonara N (2009) External knowledge sources and proximity. Journal of Knowledge Management 13: 301-318.

Meyer AD, Tsui AS and Hinings CR (1993) Configurational approaches to organizational analysis. Academy of Management Journal 27.

Miles M, Huberman M and Sdana J (2014) Qualitative Data Analysis: A Methods Sourcebook. London: Sage.

Morgulis-Yakushev S and Sölvell Ö (2017) Enhancing dynamism in clusters: a model for evaluating cluster organizations? Bridge-building activities across cluster gaps. Competitiveness Review 27: 98-112.

Motoyama Y (2008) What was new about the cluster theory? What could it answer and what could it not answer? Economic Development Quarterly 22: 353-363.

Nelson RR (1993) National Innovation Systems: A Comparative Analysis. Oxford: Oxford University Press.

Nenonen S and Storbacka K (2010) Business model design: conceptualizing networked value co-creation. International Journal of Quality and Service Sciences 2: 43-59.

Normann R and Ramirez R (1993) From value chain to value constellation: designing interactive strategy. Harvard Business Review 71: 65-77.

O'Dwyer M, O'Malley L, Murphy S and McNally RC (2015) Insights into the creation of a successful MNE innovation cluster. Competitiveness Review 25: 288-309.

OECD (2011) Regions and Innovation Policy. Paris: Organisation for Economic Co-operation and Development.

Palo T and Tähtinen J (2011) A network perspective on business models for emerging technology-based services. Journal of Business \& Industrial Marketing 26: 377-388. 
Parto S (2008) Innovation and economic activity: an institutional analysis of the role of clusters in industrializing economies. Journal of Economic Issues 42:1005-1030.

Porter ME (1998a) Competitive Advantage of Nations. New York: Free Press.

Porter ME (1998b) Clusters and the new economics of competition. Harvard Business Review 76: 77-9o.

Raymond L and Blili S (1997) Adopting EDI in a network enterprise: the case of subcontracting SMEs. European Journal of Purchasing \& Supply Management 3: 165-175.

Renko M, Carsrud A, Brannback M and Jalkanen J (2005) Building market orientation in biotechnology SMEs: balancing scientific advances. International Journal of Biotechnology 7: 250-268.

Rosenfeld SA (1997) Bringing business clusters into the mainstream of economic development. European Planning Studies 5: 3-23.

Rousseau DM (2012) Envisioning Evidence-Based Management. In: The Oxford Handbook of Evidence-Based Management. Oxford: Oxford University Press.

Scott S, Hughes M and Kraus S (2019) Developing relationships in innovation clusters. Entrepreneurship \& Regional Development 31: 22-45.

Sellitto C and Burgess S (2005) A government-funded internet portal as a promoter of regional cluster relationships: a case study from the Australian wine industry. Environment and Planning C: Government and Policy 23: 851-866.

Shaw DR and Allen T (2016) Studying innovation ecosystems using ecology theory. Technological Forecasting and Social Change.

Sölvell Ö, Lindqvist G and Ketels C (2003) The Cluster Initiative Greenbook. Stockholm: Ivory Tower.

Stabell CB and Fjeldstad ØD (1998) Configuring value for competitive advantage: on chains, shops, and networks. Strategic Management Journal 19: 413-437.

Tranfield D, Denyer D and Smart P (2003) Towards a methodology for developing evidence-informed management knowledge by means of systematic review. British Journal of Management 14: 207-222.

Viachka A (2013) Comparing firms' associational strategies across sectors and locations: cluster initiatives as meta-organizations. Stockholm School of Economics.

Viljamaa K (2007) Technological and cultural challenges in local innovation support activities - emerging knowledge interactions in Charlotte's motor sport cluster. European Planning Studies 15: 1215-1232.

Volberda HW, van derWeerdt N, Verwaal E, Stienstra M and Verdu AJ(2012) Contingency fit, institutional fit, and firm performance: a metafit approach to organizationenvironment relationships. Organization Science 23: 1040-1054.

Wannenmacher D and Antoine A (2016) Management of innovative collaborative projects: moments of tension and the peer-mediation process - a case-study approach. Knowledge Management Research \& Practice 14: 35-45. 
Wei J, Zhou M, Greeven M and Qu H (2016) Economic governance, dual networks and innovative learning in five Chinese industrial clusters. Asia Pacific Journal of Management 33: 1037-1074.

Wirtz BW, Pistoia A, Ullrich S and Göttel V (2016) Business models: origin, development and future research perspectives. Long Range Planning 49: $36-54$.

Wolfe RA (1994) Organizational innovation: review, critique and suggested research directions. Journal of Management Studies 31: 405-431.

Yström A and Aspenberg H (2017) Open for innovation? Practices supporting collaboration in Swedish regional clusters. International Journal of Innovation Management: 1740008.

Zettinig P and Vincze Z (2012) How clusters evolve. Competitiveness Review: An International Business Journal 22(2): 110-132.

Zhong Q and Tang T (2018) Impact of government intervention on industrial cluster innovation network in developing countries. Emerging Markets Finance and Trade 54: $3351-3365$.

Zott C, Amit R and Massa L (2011) The business model: recent developments and future research. Journal of Management 37: 1019-1042. 